\section{1}

2

3

4

5

6

7 Trumpington Road, Cambridge CB2 1PZ, United Kingdom

8

9

10

11

12

13

14

15

16

17

18

19

20

Ahmed F. Abdalqader, Fei Jin*, Abir Al-Tabbaa

4

.

Trumpington Road, Cambridge CB2 1PZ, United Kingdom

Trumpington Road, Cambridge CB2 1PZ, United Kingdom

* Corresponding author

Email: leonking1987@gmail.com

14

0

.

\title{
Characterisation of reactive magnesia and sodium carbonate-activated fly ash/slag paste blends
}

Ahmed F. Abdalqader: PhD candidate, Department of Engineering, University of Cambridge,

Fei Jin: Research Associate, Department of Engineering, University of Cambridge,

Abir Al-Tabbaa: PhD, Professor in Department of Engineering, University of Cambridge, 
Abstract: A system of alkali-activated fly ash (FA)/slag (AAFS) mixtures as a clinkerless cement was investigated with different dosages of $\mathrm{Na}_{2} \mathrm{CO}_{3}$, as a sustainable activator. The effect of incorporating various proportions of reactive magnesia $(\mathrm{MgO})$ was also examined. Mechanical, mineralogical, and microstructural characterisation of the cement pastes was carried out using the unconfined compressive strength, X-ray diffraction, thermogravimetric analysis, infrared spectroscopy and scanning electron microscopy. It was found that the strength of $\mathrm{Na}_{2} \mathrm{CO}_{3}$ activated FA/slag mixtures generally increased with time and the $\mathrm{Na}_{2} \mathrm{CO}_{3}$ dosage. The hydration products were mainly C-(N)-A-S-H gel of low-crystallinity, which is rich in $\mathrm{Al}$ and may have included $\mathrm{Na}$ in its structure, and hydrotalcite-like phases. Adding reactive $\mathrm{MgO}$ in the mixes showed an accelerating effect on the hydration rate as suggested by the isothermal calorimetry data. Additionally, findings revealed variations on the strength of the pastes and the chemical compositions of the hydration products by introducing reactive $\mathrm{MgO}$ into the mixtures.

Keywords: Fly ash, Slag, Reactive magnesia, Sodium carbonate, Hydration, Microstructure

\section{Highlights:}

1. $\mathrm{Na}_{2} \mathrm{CO}_{3}$ activated fly ash/slag pastes were characterised by strength, hydration properties and microstructure.

2. Increasing the $\mathrm{Na}_{2} \mathrm{CO}_{3}$ content from $5 \%$ to $10 \%$ resulted in a remarkable increase in strength and hydration rate.

3. Incorporating reactive $\mathrm{MgO}$ to the blends has a notable influence on the reaction rate, the microstructure of the mixes and slight influence on the strength.

4. Hydration products include mainly C-(N)-A-S-H gel, hydrotalcite-like phases, calcite, and gaylussite. 


\section{Introduction}

Portland cement (PC) and concrete are extensively used in the construction industry because of their remarkable technical performance and durability as well as their low cost. However, they are responsible for detrimental impacts on the environment because of their large consumption of natural resources, mass disposal of wastes, and the energy intensiveness and high carbon dioxide $\left(\mathrm{CO}_{2}\right)$ emissions of cement production. The production of PC, currently at more than 3 billion tonnes annually, is predicted to reach more than 4 billion tonnes per year by 2050 [1,2]. Approximately $0.85-1.0$ tonne of $\mathrm{CO}_{2}$ is emitted per tonne of cement clinker produced [3], which is responsible for $8-10 \%$ of the total man-made $\mathrm{CO}_{2}$ emissions [4]. This places huge pressures on the cement and concrete industries to apply more sustainable practices. Optimising the production process of PC, using waste as fuel and raw materials, using renewable energy, and replacing the clinker partially or completely with industrial by-products, are all applied to minimise the negative environmental impact of PC production [5]. Another promising and more sustainable alternative is the use of alkaliactivated cements (AACs) using industrial by-products. In this system, alkalis are introduced to silica aluminate materials (e.g., natural waste or industrial by-products) to raise the $\mathrm{pH}$ of the solution, thereby facilitating the breakage of the Si-O-Si and Al-O-Si bonds and starting the reactions to form a condensed structure [6,7]. Rashad [8] stated that AAC concrete compared to PC concrete could be $70 \%$ and $60 \%$ lower in global warming potential and energy consumption, respectively.

The extensively used materials for AACs are slag and fly ash (FA) [9]; the former is called alkali-activated slag (AAS) and the latter is known as geopolymer. Many previous studies investigated either alkali-activated slag or fly ash. As for the combined use of both, only a few studies were reported recently [10,11]. Given the limited global resources of the individual 
by-products, combining them would provide a much bigger resource and counterbalance the disadvantages of each activation process [12]. The main hydration products of the alkaliactivated FA/slag (AAFS) system are calcium silicate hydrates (C-S-H) gel, hydrotalcite-like phases, pirssonite $\left(\mathrm{Na}_{2} \mathrm{Ca}\left(\mathrm{CO}_{3}\right) \cdot \mathrm{H}_{2} \mathrm{O}\right)$, and calcite [12]. Chi and Huang [13] studied the binding mechanism and properties of AAFS mortars and concluded that better properties, compared to PC, have been obtained in terms of compressive strength, flexural strength and water absorption, although drying shrinkage was the major problem.

The most widely used activators are $\mathrm{NaOH}$, waterglass (sodium silicate), and a combination of both. These activators, however, are a source of concerns because they are the most expensive component in the system and the primary source of greenhouse gas (GHG) emissions in the production of AAC concrete. In addition, these activators would cause the AACs to shrink and harden more rapidly than what is desirable [14]. The use of sodium carbonate $\left(\mathrm{Na}_{2} \mathrm{CO}_{3}\right)$ as an activator is much less extensively studied in AACs although it has been shown that buildings made of $\mathrm{Na}_{2} \mathrm{CO}_{3}$-activated binders remained sound and increased in strength over their service life under conditions in which PC deteriorated rapidly [15]. Compared to other conventional activators, $\mathrm{Na}_{2} \mathrm{CO}_{3}$ yields a lower early age strength due to its lower $\mathrm{pH}$ but it can demonstrate higher strength at late ages than $\mathrm{NaOH}$ resulting from the effect of $\mathrm{CO}_{3}^{-2}$ ions [16], which lead to the formation of carbonated compounds that improve the mechanical strength [17]. $\mathrm{Li}$ and $\mathrm{Sun}[18]$ used $\mathrm{Na}_{2} \mathrm{CO}_{3}$ with or without $\mathrm{NaOH}$ to activate slag alone and a combination of slag and fly ash. The compressive strength of $10 \% \mathrm{Na}_{2} \mathrm{CO}_{3^{-}}$ activated slag developed from $0 \mathrm{MPa}$ at 3 days to $60 \mathrm{MPa}$ at 28 days. Recently, Bernal et al [19] examined the activation mechanism of $\mathrm{Na}_{2} \mathrm{CO}_{3}$-activated slag. They proposed that the activation took place in three different stages starting with the dissolution of the slag and the formation of gaylussite and zeolite A in the first day. Then the reaction might go through an 
extended induction period of 4-6 days with the conversion of gaylussite to $\mathrm{CaCO}_{3}$ and the formation of hydrotalcite. In the last stage, the precipitation of C-A-S-H gel started [19].

Magnesia, $\mathrm{MgO}$, is mainly produced from the calcination of magnesite, $\mathrm{MgCO}_{3}$, at different temperatures resulting in different grades [20]. The use of hard burned $\mathrm{MgO}$, calcined at 900$1200^{\circ} \mathrm{C}$, as a shrinkage compensating additive in the construction of the Baishan dam in China in the mid of 1970 s proved its efficiency and potential over the conventional admixtures [21]. Ground granulated blastfurnace slag (GGBS) normally contains a high content of $\mathrm{MgO}$, which is in the slag glass network, sometimes up to $13 \%$; whereas reactive grade $\mathrm{MgO}$ (calcined under $1000{ }^{\circ} \mathrm{C}$ ) or hard burned $\mathrm{MgO}$ (calcined at $1000-1400^{\circ} \mathrm{C}$ ) are often chosen for use as additives. Recent work found that reactive $\mathrm{MgO}$ can efficiently activate the GGBS and showed higher strength than hydrated lime activated GGBS [22,23]. The main hydration products of MgO-GGBS system were C-S-H and hydrotalcite-like phases [24]. The reaction of such system depends on the properties of $\mathrm{MgO}$ [24], which strongly depend on the source of the precursor and the calcination history [25].

There are very limited reports regarding the effect of reactive $\mathrm{MgO}$ in AACs. Ben Haha et al. [26] studied the effect of high inherent $\mathrm{MgO}$ content on alkali activated slag and found that for waterglass activated slag paste, the compressive strength after 28 days increased by 50$80 \%$ with increasing $\mathrm{MgO}$ content from 8 to $13 \%$. This was because the higher $\mathrm{MgO}$ content contributed to more hydrotalcite-like phases formed, resulting in up to $9 \%$ higher volume of hydrates and a lower porosity. Additionally, Shen et al. [27] studied the properties of reactive $\mathrm{MgO}$ modified alkali activated fly ash/slag cement (MAAFS) and concluded that the blends can reach the strength standard of $42.5 \mathrm{~N}$. They also showed that adding $\mathrm{MgO}$ reduced the shrinkage and cracking tendency due to its expansive hydration [27]. Kwok [28] studied the effect of reactive $\mathrm{MgO}$ in $\mathrm{Na}_{2} \mathrm{CO}_{3}$-activated slag/limestone systems and found that replacing 
limestone by reactive $\mathrm{MgO}$ remarkably increased the early strength and slightly increased the 28-day strength. The effect of $\mathrm{MgO}$ reactivity on the strength, shrinkage, and microstructure of sodium silicate and sodium carbonate-activated slag was studied by [29-31]. They found that adding reactive $\mathrm{MgO}$ into the $\mathrm{AAC}$ can effectively reduce the drying shrinkage and increase the strength depending on the reactivity and the content of reactive MgO. However, there is no literature on the role of reactive $\mathrm{MgO}$ in $\mathrm{Na}_{2} \mathrm{CO}_{3}$-activated slag/fly ash system.

Hence the aim of this paper is to examine the effect of combining reactive $\mathrm{MgO}$ and $\mathrm{Na}_{2} \mathrm{CO}_{3}$ for the activation of fly ash and slag blends on the strength, reaction kinetics, and hydration products and microstructure.

\section{Materials and Methods}

The GGBS used was supplied by Hanson cement, UK, and has basicity $\left(K_{b}=\frac{\mathrm{CaO}+\mathrm{MgO}}{\mathrm{SiO}_{2}+\mathrm{Al}_{2} \mathrm{O}_{3}}\right)$ and hydration modulus $\left(\mathrm{HM}=\frac{\mathrm{CaO}+\mathrm{MgO} \mathrm{Al}_{2} \mathrm{O}_{3}}{\mathrm{SiO}_{2}}\right)$ values of $\sim 1.0$ and $\sim 1.60$, respectively. The GGBS was mainly amorphous with a broad hump in the $2 \theta$ region of $25-38^{\circ}$ in the XRD pattern (not shown). Merwinite $\left(\mathrm{Ca}_{3} \mathrm{Mg}\left(\mathrm{SiO}_{4}\right)_{2}\right)$ was identified as the only crystalline phase present. The FA was obtained from Cemex, Rugby, UK and is classified to meet the requirements of the British standard for use with PC (BS 3892: Part 1). The MgO was obtained from Richard Baker Harrison, UK, and has a reactivity of $170 \mathrm{sec}$ according to the acetic acid test, which indicates medium reactivity according to the classification of Jin and Al-Tabbaa [25]. The chemical compositions of all materials are shown in Table 1. Sodium carbonate was supplied by Fisher scientific, UK as a powder and has the purity of $99 \%$. It was dissolved in the mix water until complete dissolution was reached. 
Table 1 Chemical composition and physical characteristics of the materials used (based on the

\begin{tabular}{llll}
\hline Component & GGBS & FA & $\mathrm{MgO}$ \\
\hline $\mathrm{CaO} \%$ & 39.24 & $6.8 \pm 3.6$ & 1.9 \\
\hline $\mathrm{SiO}_{2} \%$ & 36.79 & $49.3 \pm 6.2$ & 0.9 \\
\hline $\mathrm{Al}_{2} \mathrm{O}_{3} \%$ & 11.51 & $24.1 \pm 0.4$ & 0.1 \\
\hline $\mathrm{Fe}_{2} \mathrm{O}_{3}$ & 0.42 & $9.7 \pm 1.3$ & 0.8 \\
\hline $\mathrm{MgO} \%$ & 8.10 & $1.1 \pm 0.2$ & 93.5 \\
\hline $\mathrm{SO}_{3} \%$ & 1.03 & $3.3 \pm 1.3$ & - \\
\hline $\mathrm{K}_{2} \mathrm{O} \%$ & 0.63 & $3.5 \pm 0.3$ & - \\
\hline $\mathrm{Na}_{2} \mathrm{O} \%$ & 0.37 & $1.2 \pm 0.1$ & - \\
\hline $\mathrm{SSA}\left(\mathrm{m}^{2} / \mathrm{kg}\right)$ & 545 & 2600 & - \\
\hline
\end{tabular}

143 Clinkerless systems were prepared from GGBS, FA, and $\mathrm{MgO}$ and activated by $\mathrm{Na}_{2} \mathrm{CO}_{3}$. All mixes had a water to binder $(\mathrm{w} / \mathrm{b})$ ratio of 0.31 . Each material is given an appropriate notation for simplicity. G, F, M, and $\mathrm{N}$ refer to GGBS, FA, $\mathrm{MgO}$, and $\mathrm{Na}_{2} \mathrm{CO}_{3}$, respectively. The ratio of GGBS to FA was fixed at 3 parts to 1 part by weight. The proportion of $\mathrm{MgO}$ changed from 0 to $10 \%$ by replacing GGBS+FA and the content of $\mathrm{Na}_{2} \mathrm{CO}_{3}$ varied from $0-10 \%$ by the weight of the total binder as shown in Table 2 .

\begin{tabular}{lllll}
\hline Mix & GGBS $\%$ & $\mathrm{FA} \%$ & $\mathrm{MgO} \%$ & $\mathrm{Na}_{2} \mathrm{CO}_{3} \%$ \\
\hline GFM5N0 & 71.25 & 23.75 & 5 & 0 \\
\hline GFM10N0 & 67.5 & 22.5 & 10 & 0 \\
\hline GFM0N5 & 75 & 25 & 0 & 5 \\
\hline GFM5N5 & 71.25 & 23.75 & 5 & 5 \\
\hline GFM10N5 & 67.5 & 22.5 & 10 & 5 \\
\hline GFM0N10 & 75 & 25 & 0 & 10 \\
\hline GFM5N10 & 71.25 & 23.75 & 5 & 10 \\
\hline GFM10N10 & 67.5 & 22.5 & 10 & 10 \\
\hline
\end{tabular}

151 For the preparation of the paste samples, all the dry materials (GGBS, FA, and MgO) were 152 mixed by hand in a bowl followed by 5 minutes' dry mixing in a mixer to which the $\mathrm{Na}_{2} \mathrm{CO}_{3}$ 153 solution was then added. The mixer was stopped after 3 minutes of slow mixing, to collect 
any unmixed solids scraped from the sides of the mixing bowl and the paddle into the bowl. Then 2 more minutes of slow mixing and 5 minutes of fast mixing were applied to ensure homogeneity. For each mix, the freshly mixed cement paste was placed into 40 x 40 x $40 \mathrm{~mm}$ steel cubic moulds in three layers, and in between each layer the mixture was tapped with a spatula for at least 25 times in two directions to remove the air voids. The samples were demoulded after 2 days of curing and then cured in a water tank at temperatures between $20 \pm$ $2{ }^{\circ} \mathrm{C}$ until the designed testing age. The demoulding time was done after $48 \mathrm{hrs}$ because some mixes were too soft to be demoulded after $24 \mathrm{hrs}$ in agreement to [32].

Isothermal calorimetry experiments were conducted using a TAM Air Isothermal calorimeter, at a base temperature of $20 \pm 0.02{ }^{\circ} \mathrm{C}$. Fresh paste was mixed externally, weighed into an ampoule, and immediately placed in the calorimeter, and the heat flow was recorded for the first 140 hrs of reaction. All values of heat release rate were normalised by total weight of the paste.

The compressive strength testing was carried out using Controls Advantest 9 with a maximum capacity of $250 \mathrm{kN}$ and a loading rate of $2400 \mathrm{~N} / \mathrm{s}$. Triplicate cubes were tested at ages of 3, 7, 28, 56 and 90 days and the strength reported was an average of the three specimens. Immediately after the compressive strength test at 28days, selected samples for microstructural analyses were immersed in acetone for three days in order to stop any further hydration. Then the samples were filtered to remove the acetone followed by vacuum drying in a desiccator. The samples were then put in the oven at $60^{\circ} \mathrm{C}$ for at least $24 \mathrm{hrs}$. Thereafter, part of the samples was crushed and ground in the agate mortar until passing the $75 \mu \mathrm{m}$ sieve. The powders obtained were sealed in plastic vials for further analysis.

Powder X-Ray diffraction (XRD) was employed to identify the crystalline phases in the sample. The ground powders were placed on glass microscope slides onto which acetone was 
dripped. After the acetone evaporated, the sample was affixed to the slide and placed in the Siemens D500 X-ray diffractometer with a CuKa source operating at $40 \mathrm{kV}$ and $40 \mathrm{~mA}$, emitting radiation at a wavelength of $1.5405 \AA$. The scanning regions were between $2 \theta$ values of 5 to $60^{\circ}$, at a resolution of $0.02^{\circ} /$ step. Thermogravimetric analysis (TGA) were conducted using $20 \pm 2 \mathrm{mg}$ powder under static air in an open alumina crucible heated at $10{ }^{\circ} \mathrm{C} / \mathrm{min}$ over the range of $40-1000^{\circ} \mathrm{C}$ on a Perkin Elmer STA6000 machine. Attenuated Total Reflectance Fourier Transform Infrared (ATR-FTIR) spectra of the samples were taken using Perkin Elmer FTIR Spectrometer Spectrum 100 Optica. Spectra were collected in transmittance mode from 4000 to $600 \mathrm{~cm}^{-1}$ at a resolution of $1 \mathrm{~cm}^{-1}$. Fractured surface specimens obtained from mechanical testing were examined by scanning electron microscope (SEM) conducted on a JEOL model JSM-820. Prior to SEM testing, the samples were mounted onto metal stubs using carbon paste and coated with gold film to ensure good conductivity. The accelerated voltage was set at $10 \mathrm{kV}$. Additionally, backscattered electron microscopy and energy dispersive X-ray analysis (EDX) were carried out on the 28-day samples using FEI Nova NanoSEM FEG at $15 \mathrm{kV}$ accelerating voltage and a working distance of $5 \mathrm{~mm}$. The samples were impregnated in epoxy resin before polishing and coated with carbon.

\section{Results and Discussions}

\subsection{Unconfined Compressive Strength (UCS)}

The compressive strengths of all the mixes at ages of $3,7,28,56$, and 90 days are shown in Fig. 1. The compressive strengths of samples containing no $\mathrm{Na}_{2} \mathrm{CO}_{3}$ were far lower than the other mixes at all ages. However, it also demonstrates that even with the absence of the alkali activator (black lines), $\mathrm{MgO}$ can activate the slag/FA blends effectively since the 3-day 
strength of $10 \% \mathrm{MgO}$ activated slag/FA blends reached $\sim 9 \mathrm{MPa}$. This is in agreement with the findings of $[22,33,34]$.

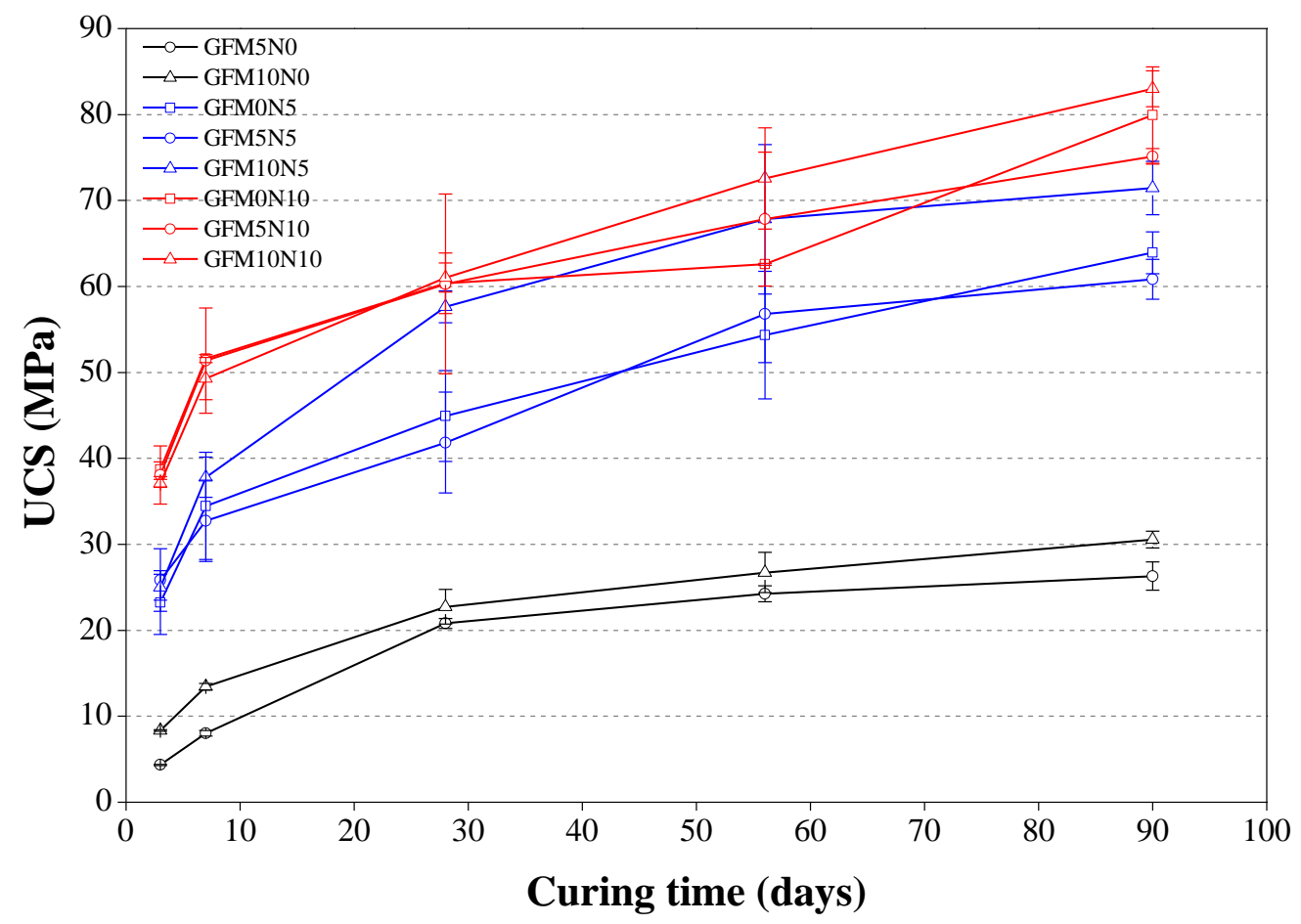

Figure 1. UCS of AAFS cements at different ages

Fig.1 also presents the effect of $\mathrm{MgO}$ on the strengths of blends activated by $5 \%$ (blue lines) and $10 \%$ (red lines) $\mathrm{Na}_{2} \mathrm{CO}_{3}$. Adding $5 \%$ of $\mathrm{MgO}$ (denoted with circles) had a marginal effect on strength, while an increase of the $\mathrm{MgO}$ content to $10 \%$ (denoted with triangles) remarkably increased the strength, especially after 28 days. The positive influence of $\mathrm{MgO}$ on the strength could be attributed to its contribution in forming hydrotalcite which densifies the microstructure [26,29]. Jin et al. [29] also showed the enhancement of strength by adding reactive $\mathrm{MgO}$ into the $\mathrm{Na}_{2} \mathrm{CO}_{3}$ activated slag pastes. The addition of $\mathrm{MgO}$ to alkali activated systems does not yield to strength loss as have been observed in PC-based systems [35,36]. This is because that $\mathrm{MgO}$ in alkali activate systems can react with the dissolved ions from the aluminosilicate precursors to yield hydrotalcite-like phase or magnesium silicate hydrate gel 
[24,29] while in PC systems it reacts separately with water to form brucite $\left(\mathrm{Mg}(\mathrm{OH})_{2}\right)$, which 213 is weaker than the strength-giving phase in PC [36].

214 It is also shown in Fig. 1 that adding $\mathrm{Na}_{2} \mathrm{CO}_{3}$ effectively activated the binders especially when 215 used at $10 \%$. The range of the compressive strengths at early ages highly depended on the 216 $\mathrm{Na}_{2} \mathrm{CO}_{3}$ dosage. There is steep strength gain before 7 days followed by a relatively gradual and almost linear gain up to 90 days for these mixes with $\mathrm{Na}_{2} \mathrm{CO}_{3}$, with final 90-day strength 218 of over $60-70 \%$ higher than the 7-day strength; whereas for mixes without $\mathrm{Na}_{2} \mathrm{CO}_{3}$, only a 219 slight strength gain was obtained after 28 days. The early age strength improvement by $220 \mathrm{Na}_{2} \mathrm{CO}_{3}$ can be attributed to the higher $\mathrm{pH}$ of the pore solutions which accelerate the 221 dissolution of slag and FA. The remarkable strength development at later ages can be attributed to the effect of carbonate ions as proposed by [15]. These data suggest that activating slag/FA with $\mathrm{Na}_{2} \mathrm{CO}_{3}$ and incorporating $\mathrm{MgO}$ can yield strengths as high as 60 $\mathrm{MPa}$ at 28 days and as high as $80 \mathrm{MPa}$ at 90days.

225 In the very few available reports about the strength of formulae activated by $\mathrm{Na}_{2} \mathrm{CO}_{3}$, lower 226 strength have been reported following similar conditions of the current study [19,28,32,37], 227 although they reported higher strength in special curing conditions[38]. Therefore, emphasis in this work is placed on the fact that no high-temperature curing (all samples cured at room 229 temperature) or complicated fabrication techniques (autoclave curing, humidity chamber 230 curing, etc...) were used, making these formulae both practical for large-scale usage and of 231 reduced environmental impact. Therefore, the greatly reduced environmental impact, the 232 simplicity of manufacture, and the use of natural reactants $\left(\mathrm{Na}_{2} \mathrm{CO}_{3}\right)$ are all reasons for further 233 investigation of these materials. 


\subsection{Isothermal Calorimetry}

235 The heat release curves of mixes containing different percentages of $\mathrm{MgO}$ are shown in Fig. 236 2. There is an initial pre-induction period, associated with the partial dissolution of the slag and fly ash. This period is then followed by an extended induction period where little heat evolution was taking place. It is clear that increasing the activator dosage and the $\mathrm{MgO}$ content shortened this period. This indicates that the addition of $\mathrm{MgO}$ and increasing the activator dosage accelerate the reaction rate. The mix with $10 \% \mathrm{MgO}$ led to higher heat of reaction (Fig. 2b) which means that an increased precipitation of reaction products occurred. The $\mathrm{MgO}$ content of slag has recently been identified to play a vital role in the kinetic of the reaction of alkali activated slag binders [39]. A high intensity heat evolution process between 40-70 $\mathrm{h}$ and 30-60 $\mathrm{h}$ in binders containing $5 \% \mathrm{Na}_{2} \mathrm{CO}_{3}$ and $10 \% \mathrm{Na}_{2} \mathrm{CO}_{3}$, respectively, was identified. This peak refers to the acceleration and deceleration processes when the precipitation of voluminous reaction products occurs, thereby releasing a significant heat of reaction. The occurrence and timing of this period explain the need for keeping the samples in the moulds up to 48 hours before demoulding and confirm that the formation of the strengthgiving phases takes place during the first 48 hours. These results are different from [19], where the pre-induction and induction periods extended to more than $100 \mathrm{~h}$, or sodium silicate-activated slag [26], which suggests that that the reaction kinetic is not only dependent on the alkaline activator but also on the chemical and physical properties of slag. 


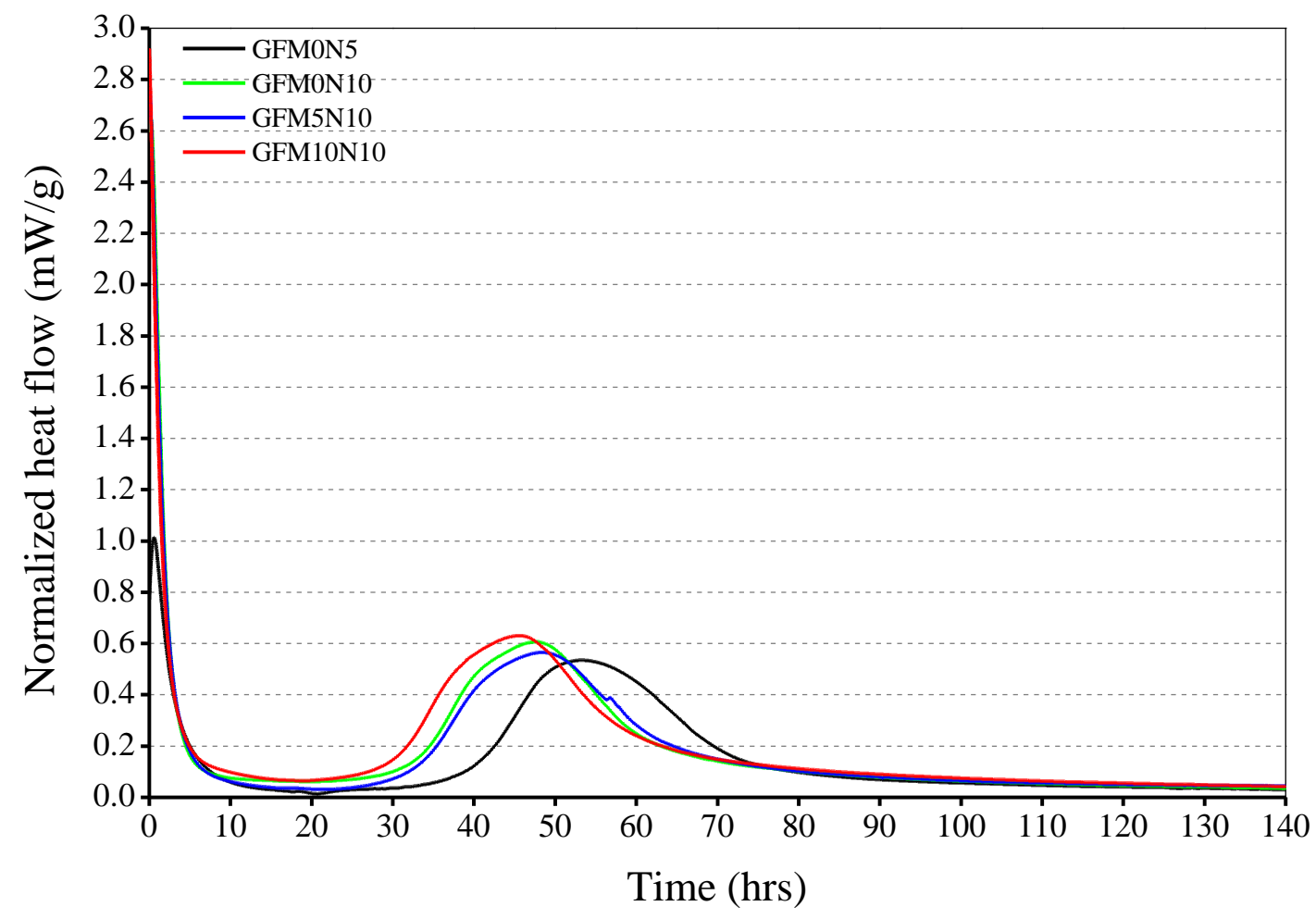

(a)

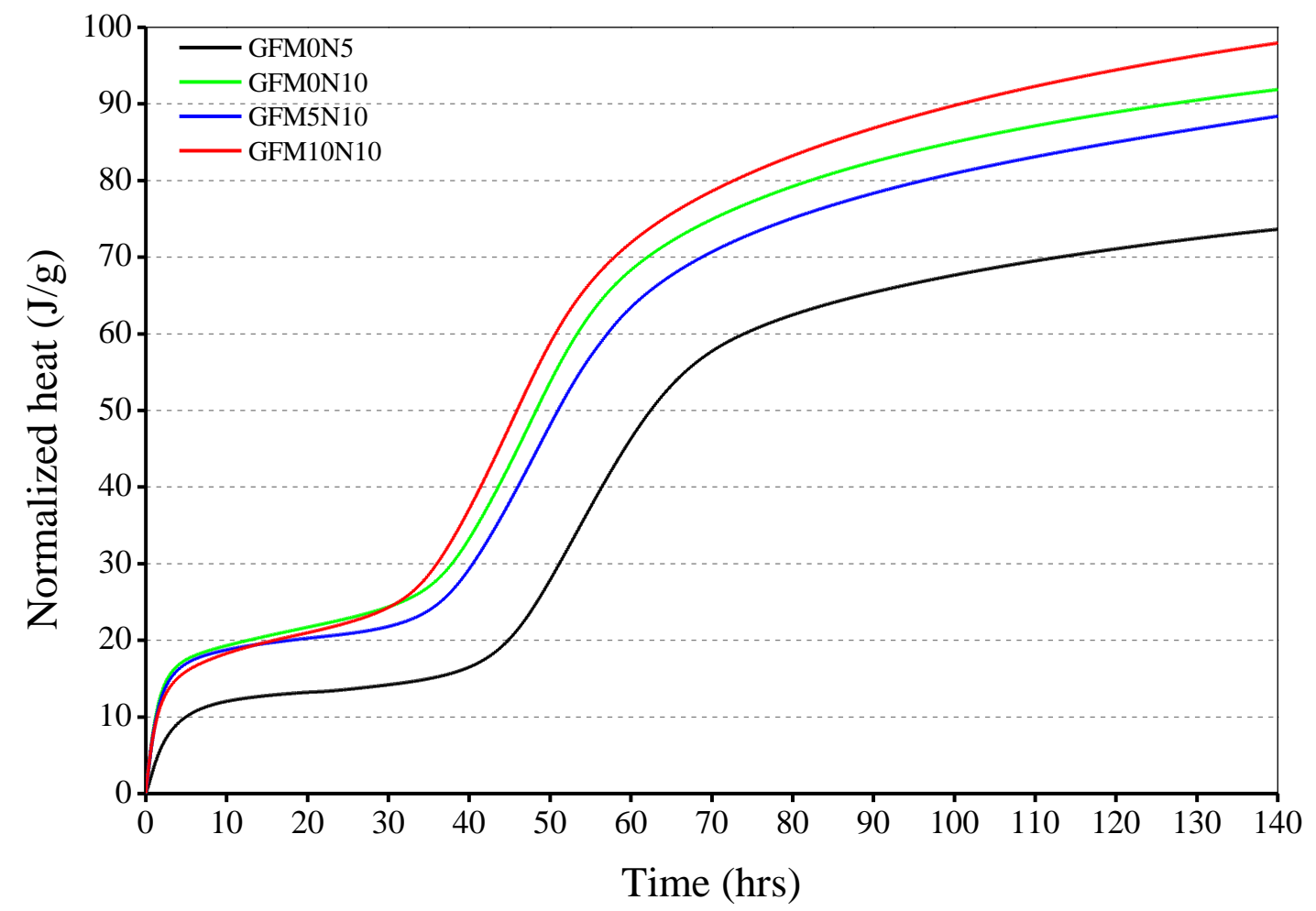

(b)

Figure 2. Heat release rate (a) and cumulative heat release (b) of different mixes 


\subsection{Hydration Products}

254 The evolution of crystalline phases in the mixes at different ages is shown Fig. 3. In samples 255 cured for 3 days (Fig. 3a), the broad hump present in the non-hydrated slag in the $2 \theta$ region of $25625-38^{\circ}$ slightly diminished during the first days of hydration and a new diffuse peak at about $2572 \theta=29.5^{\circ}$ appeared. This peak is assigned to C-S-H phase or calcite. C-S-H is generally considered to be poorly crystalline but its crystallinity in alkali-activated slag has already been reported by [40]. However, calcite occurrence is possible due to the recarbonation of $\mathrm{Ca}$ with $\mathrm{CO}_{3}{ }^{2-}$ ions as reported by [15,37] along with other calcium carbonate polymorphs such as vaterite and aragonite[19]. Another main crystalline phase is the double salt gaylussite

$262\left(\mathrm{Na}_{2} \mathrm{Ca}\left(\mathrm{CO}_{3}\right)_{2} .5 \mathrm{H}_{2} \mathrm{O}\right)$, which is known to form as a natural evaporite in alkali lake waters between the dissolved $\mathrm{CO}_{3}{ }^{2-}$ and the $\mathrm{Ca}^{2+}$ released from the partial dissolution of the slag.

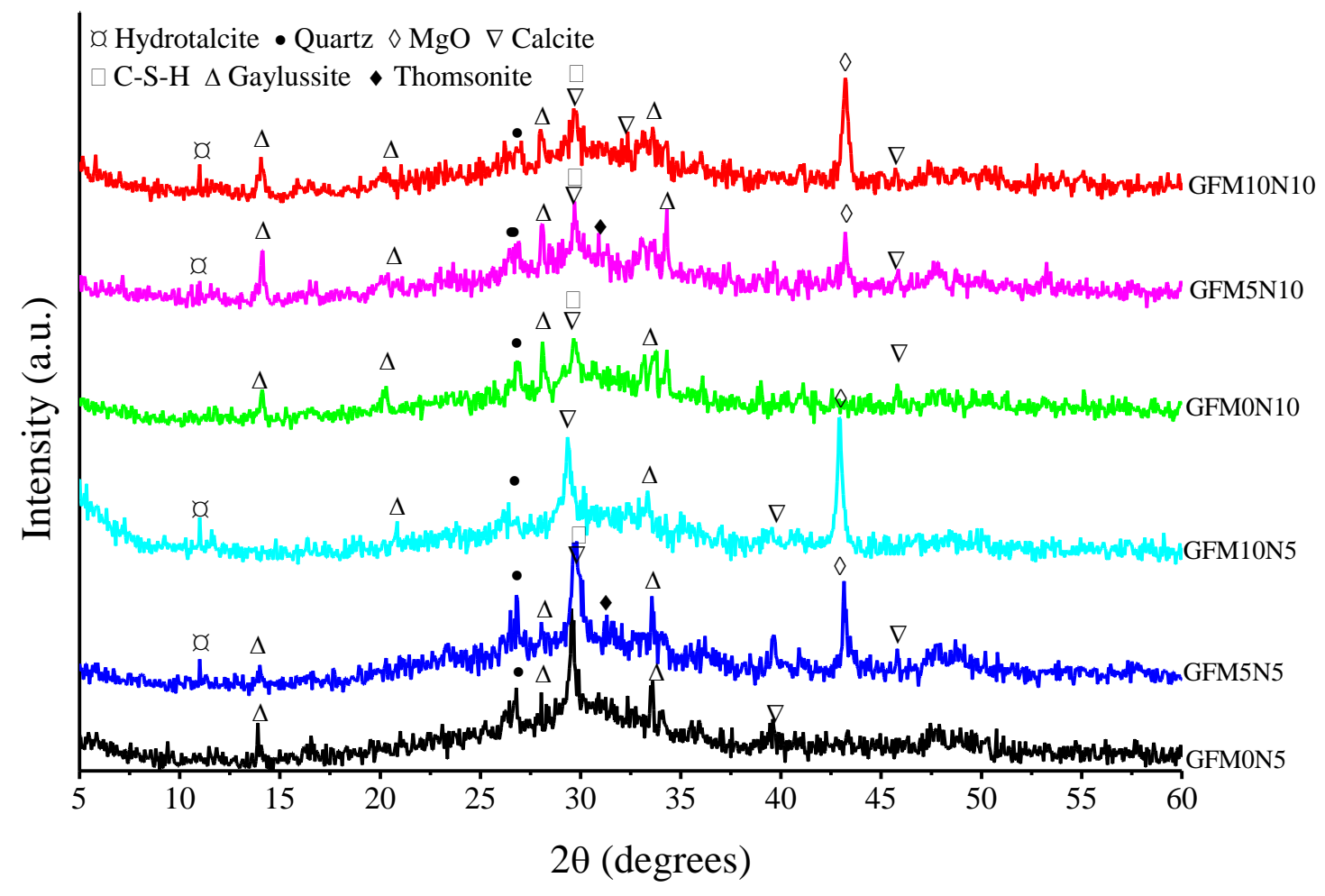

(a) 


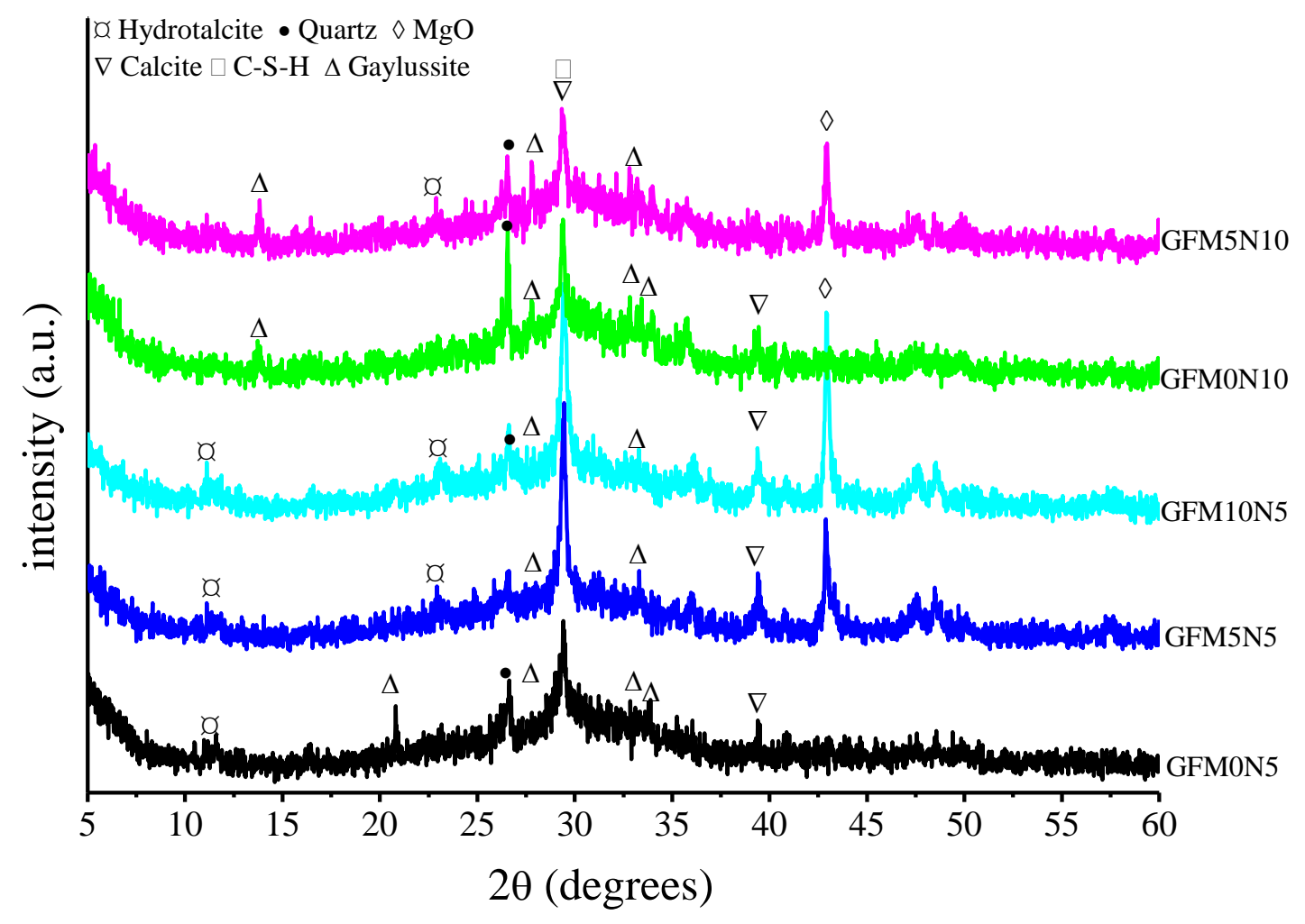

(b)

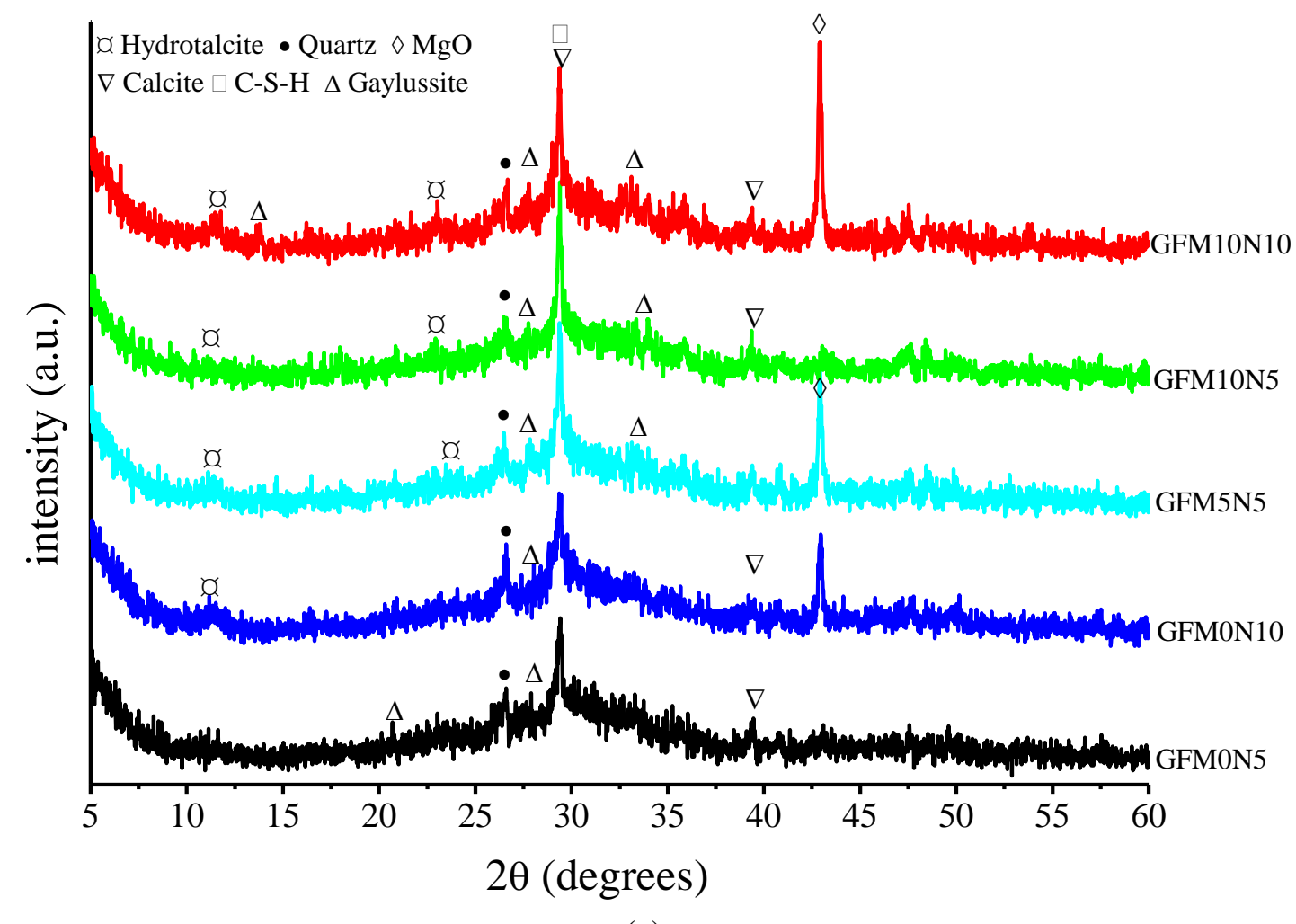

(c)

Figure 3. XRD of cement pastes at (a) 3 days, (b) 28 days, and (c) 180 days 
Additionally supply from $\mathrm{MgO}$ could enhance the formation of hydrotalcite as it is defined as an $\mathrm{Mg}$-Al double-layered hydroxide. Also the presence of FA increased the uptake of $\mathrm{Al}$ to form the hydrotalcite and C-(N)-A-S-H gel as some traces of thomsonite $\left(\mathrm{NaCa}_{2} \mathrm{Al}_{5} \mathrm{Si}_{5} \mathrm{O}_{20} \cdot 6 \mathrm{H}_{2} \mathrm{O}\right)$ was observed and confirmed by TGA (see below). Thomsonite has been identified in carbonated alkali-activated slag binders [42]. In addition, unreacted $\mathrm{MgO}$ and some quartz, indicating the presence of unreacted FA, were also observed.

After 28 days of curing (Fig. 3b), the peaks of gaylussite disappeared on mixes containing only $5 \% \mathrm{Na}_{2} \mathrm{CO}_{3}$ and decreased on mixes containing $10 \% \mathrm{Na}_{2} \mathrm{CO}_{3}$. Also the intensities of calcium carbonate phases decreased possibly due to the formation of more C-A-S-H and hydrotalcite like phases.

Significant increase in the intensities of the reflections assigned to hydrotalcite and C-A-S-H along with the decrease of quartz and $\mathrm{MgO}$ were observed at 180 days (Fig 3c). It is clear that the presence of $\mathrm{MgO}$ lead to the formation of more hydrotalcite-like phases and it seems that after this extended curing age that the C-A-S-H gel and hydrotalcite-like phases were the major hydration products, which agrees with the findings of [12,16,19,28,37]. Moreover, there was no clear evidence of the presence of any magnesium carbonate in these blends as reported by [27] or brucite reported by [26] which indicates that the presence of $\mathrm{MgO}$ in these system only lead to the formation of hydrotalcite-like phases or M-(A)-S-H gels intermixed with the main gel as will be discussed later. The activation of slag and FA initially consists of breakdown of the covalent bonds Si-O-Si and Al-O-Si [43]. Dissolved $\mathrm{Mg}^{2+}$ ions then either reacts with the broken bonds to form $\mathrm{M}-\mathrm{S}-\mathrm{H}$ or hydrotalcite like phases, thereby hindering the precipitation of brucite [29]. This behaviour has been reported with adding reactive magnesia to slag and silica fume $[33,44,45]$. 
The TG curves in Fig.4 show that four main humps were observed. It was found that the weight loss increased with time for all samples. The first peak observed in the DTG curves was at $85-105^{\circ} \mathrm{C}$ and is attributed to $\mathrm{C}-\mathrm{S}-\mathrm{H}$ dehydration [46]. This is consistent with the removal of free evaporable water which is present in the pores of the geopolymer gel products, either C-(A)-S-H type or N-A-S-H (zeolite-like) gels [47]. The main mass loss peak between $300^{\circ} \mathrm{C}$ and $400^{\circ} \mathrm{C}$ is due to the decomposition of hydrotalcite [16]. The loss at 500$600^{\circ} \mathrm{C}$ could be due to either the dehydration of thomsonite [48], M-S-H gel [29], or the decomposition of poorly crystallised phase of calcite $[37,49]$. The temperature range of $600-$ $800{ }^{\circ} \mathrm{C}$ is the decomposition range of various carbonate-containing phases including hydrotalcite, magnesium carbonate, and calcium carbonate [29]. These results are in good agreement with the XRD results presented above. The increase of the hydrotalcite peak with increasing the $\mathrm{MgO}$ content and with curing age was observed. The disappearance of the peak at $500-600^{\circ} \mathrm{C}$ indicates that this phase was transformed with extended curing to other phases, e.g., low crystalline calcite (vaterite) phases could be converted to a more stable phase such as calcite [19].

The total weight loss (indicating the chemically bound water content) and the bound water content in C-S-H are often used as a measurement of the hydration extent of blended cements [50]. The calculated weight losses from TG data at different ages were summarised in Table 3 , where the total weight loss was denoted as $\Delta \mathrm{m}$. It can be seen that increasing the activator dosage significantly increased the hydration degree at all ages. Increasing the content of $\mathrm{MgO}$ increased slightly the hydration degree which could indicate that the presence of $\mathrm{MgO}$ promoted the formation of more hydration products or products with more chemically bound water. However, the contents of C-S-H and $\Delta \mathrm{m}$ of the mix made of GFM10N5 was lower than those of GFM5N5 after 28 days of curing. This could be due to the reduced slag/FA 
313 was higher than that of GFM5N5. The improved strength could be attributed to the pore

314 filling effect of the unhydrated $\mathrm{MgO}$, resulting in denser microstructure. Besides, the weight

315 loss associated to hydrotalcite-like phases increased with increasing MgO contents at 28 days.

316 The reduction of these values at 28 days compared to 3 days values could be due to the

317 overestimation of the weight loss associated to this peak as it overlapped with the third peak

318 as shown in Fig. 4a. It was found the total weight loss after 180 days did not change

319 significantly but the most apparent feature at this age was the disappearance of the third peak 320 as shown in Fig. 4c.

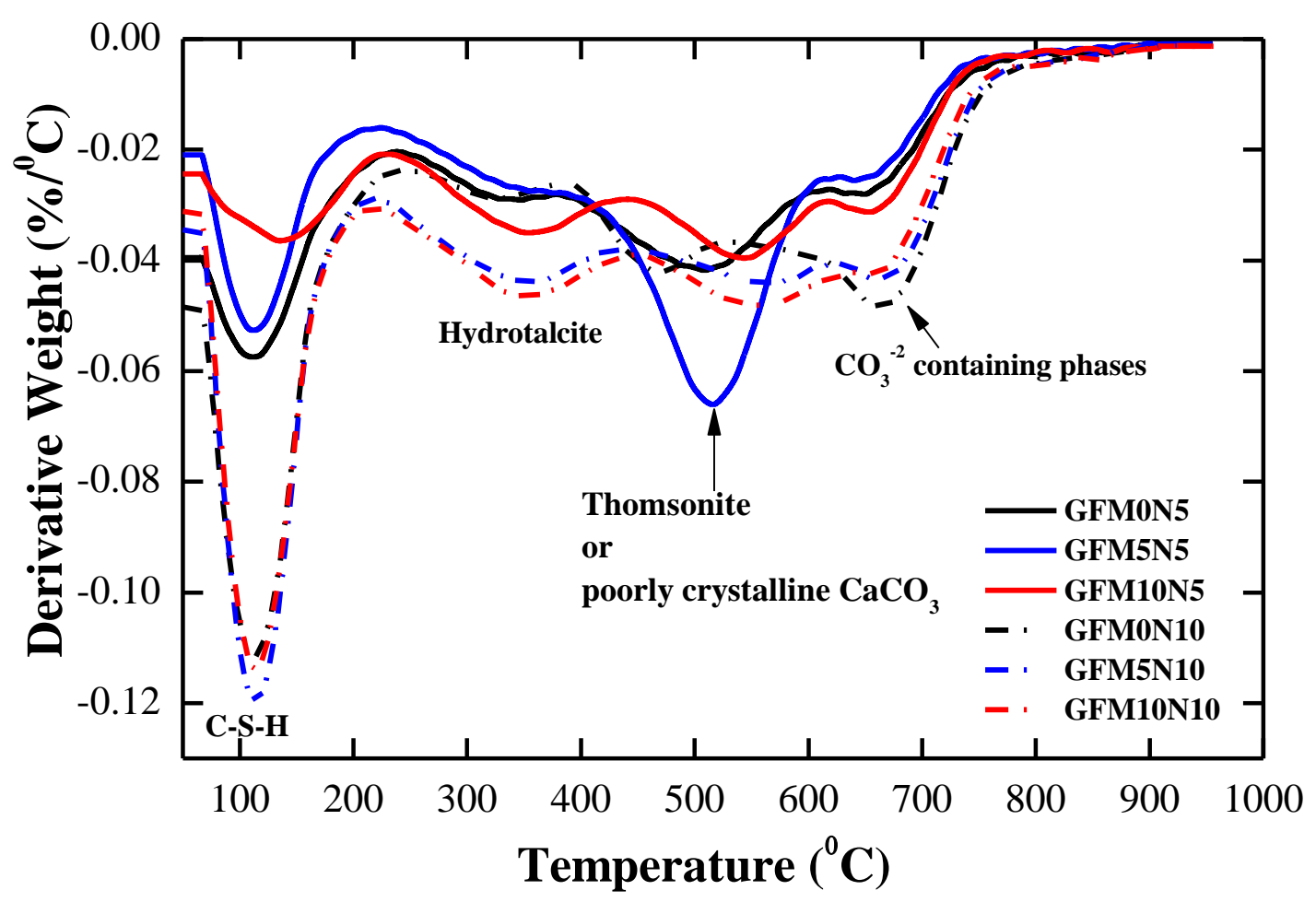

(a) 


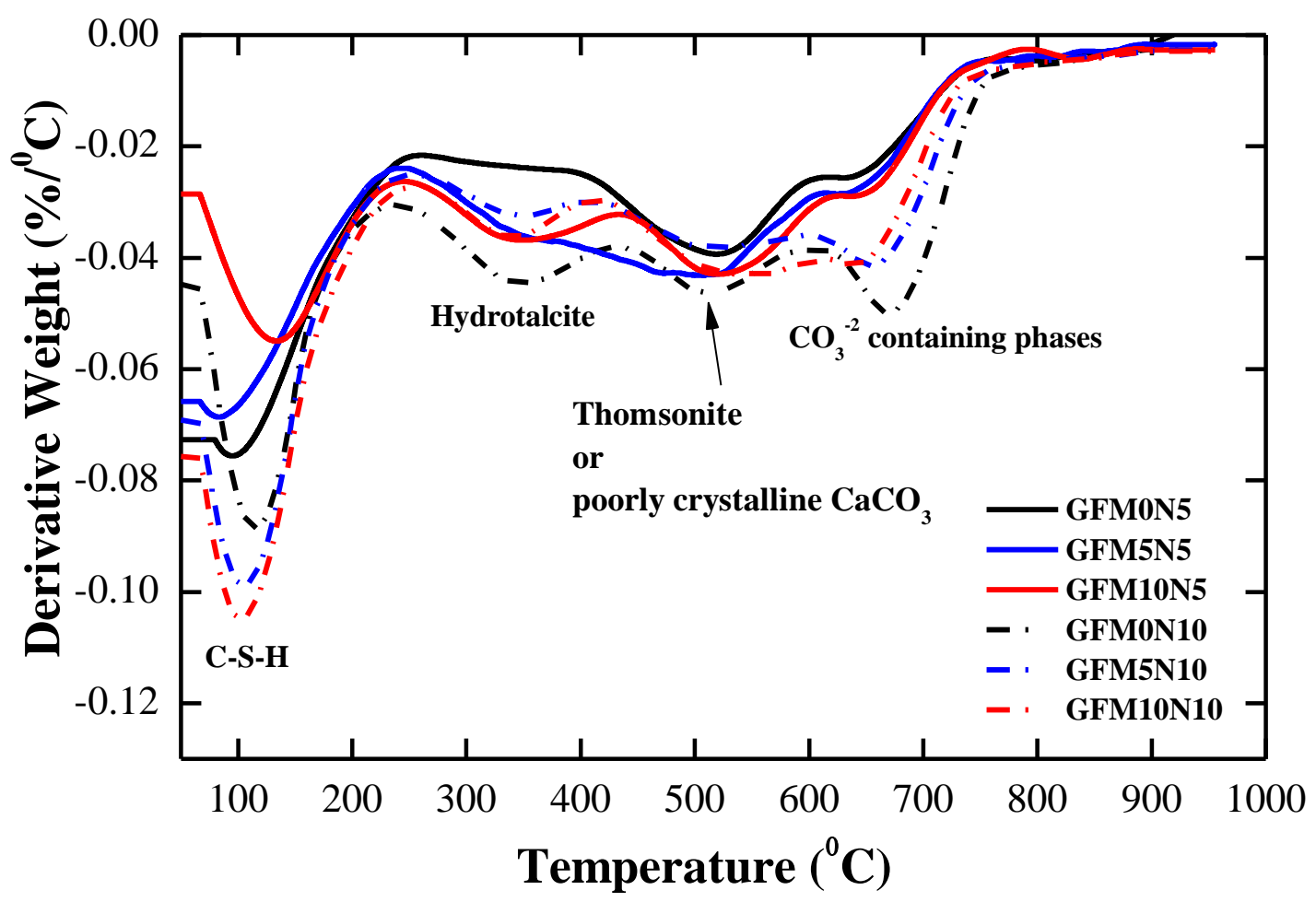

(b)

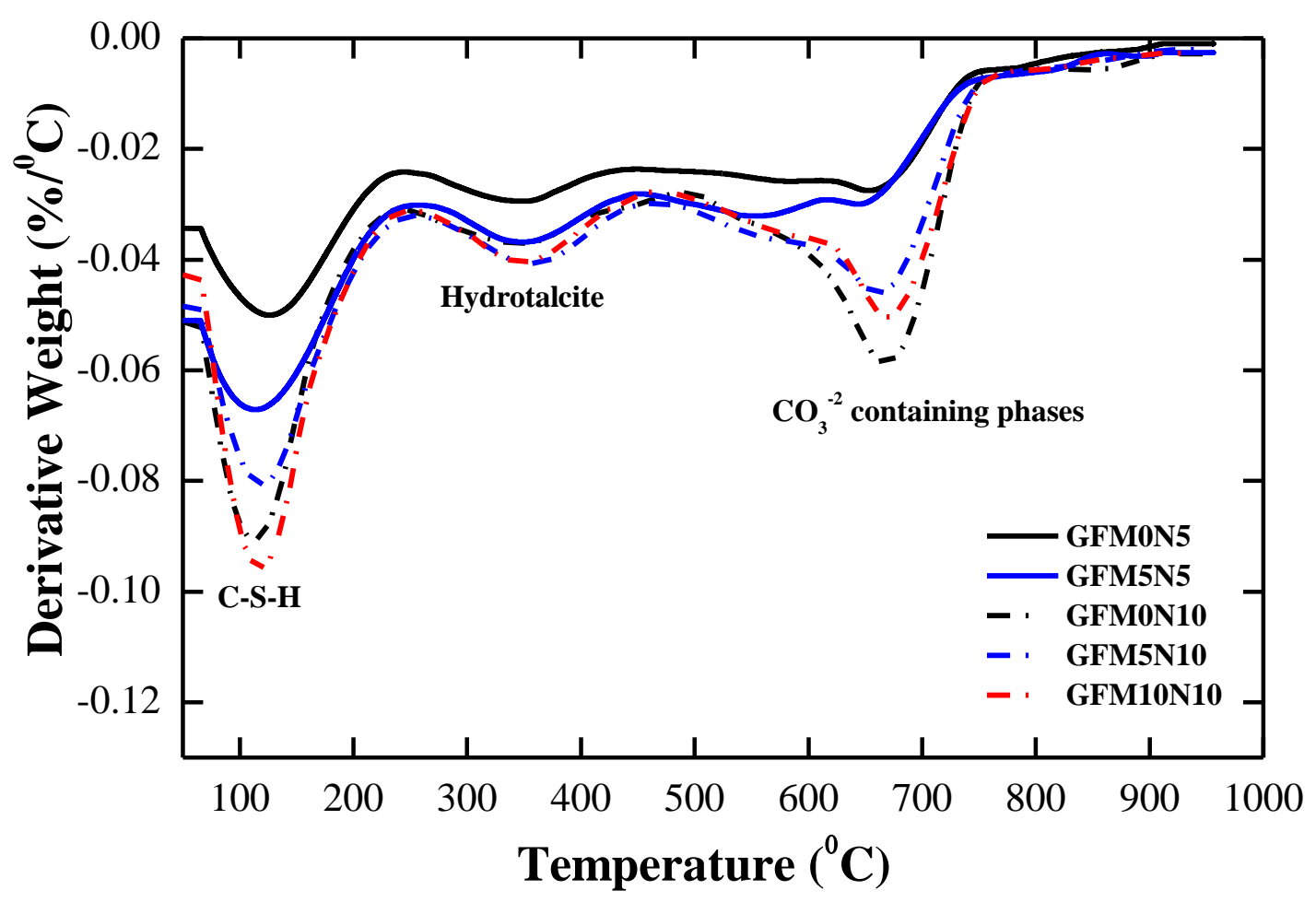

(c)

Figure 4. DTG of the mixes at (a) 3 days, (b) 28 days, and (c) 180 days 


\begin{tabular}{ccccccc}
\hline \multirow{2}{*}{ Blend } & \multicolumn{7}{c}{ Weight loss } \\
\cline { 2 - 7 } & C-S-H & Ht & $\Delta$ m & C-S-H & Ht & $\Delta$ m \\
\cline { 2 - 7 } & 4.5 & 3.05 & 12 & 5.8 & 2.38 & 12.75 \\
\hline GFM0N5 & 3 & 2.66 & 10.7 & 6.1 & 3.39 & 15 \\
\hline GFM5N5 & 3.1 & 3.13 & 10.3 & 4.75 & 3.46 & 13.75 \\
\hline GFM10N5 & 5 & 3.02 & 15.5 & 6.25 & 3.06 & 16.25 \\
\hline GFM0N10 & 5.5 & 4.16 & 15.9 & 7.9 & 3.12 & 16.75 \\
\hline GFM5N10 & 6 & 4.27 & 15.5 & 8 & 3.17 & 16.75 \\
\hline GFM10N10 & & & & & & \\
\hline
\end{tabular}

322

323

324

325

The FTIR spectra for the 28-day samples are presented in Fig.5. All the spectra show very similar bands, suggesting a very similar nature of hydration products irrespective to the activator dosage and $\mathrm{MgO}$ content used. The figure indicates major bands systems at approximately $3400,1650,1450,970$, and $860 \mathrm{~cm}^{-1}$. The structure of molecular water in the alkali activated fly ash/slag system is characterized by the $\mathrm{O}-\mathrm{H}$ stretching band, from 3,200 to $3,700 \mathrm{~cm}^{-1}$, while the bending of the chemically bonded $\mathrm{H}-\mathrm{O}-\mathrm{H}$ is located at $1,650 \mathrm{~cm}^{-1}$ [47]. Noticeable bands at 1450 and $860 \mathrm{~cm}^{-1}$ suggest the presence of $\mathrm{CO}_{3}{ }^{2-}$, which can be attributed to the presence of calcite or hydrotalcite as detected by both XRD and TGA. The strongest band in the region of $1000-900 \mathrm{~cm}^{-1}$ corresponds to the asymmetric stretching vibration of SiO-T ( $\mathrm{T}=$ tetrahedral Al, Si). The position of this band is consistent with both the C-(A)-S-H structure formed by the activation of slag in alkaline media [11,51], and the N-A-S-H gels formed in geopolymer systems derived from fly ash [52]. The typical band of these binding gels in slag and FA is between 950 and $1100 \mathrm{~cm}^{-1}$ but the shift towards a lower wavenumber indicates the reduced content of calcium in the gel formed from the activation of the slag and increased incorporation of $\mathrm{Al}$ into this gel due to the dissolution of the FA [47]. Nevertheless, the absence of the absorption band around 1000 to $1100 \mathrm{~cm}^{-1}$ indicates that the typical structure of N-A-S-H gels is not formed within the hydration products. 
The effect of $\mathrm{MgO}$ on the gel nanostructure as displayed by the FTIR spectra in Fig. 5 was

341 more determinant in mixes activated by $5 \% \mathrm{Na}_{2} \mathrm{CO}_{3}$. The principal band associated with $\mathrm{Si}$ -

342 O-T near $970 \mathrm{~cm}^{-1}$ is broader in GFM10N5 than in GFM5N5 and GFM0N5. This confirms

343 that this mix is more disordered than the others, which indicates the wide distribution of the

$344 \mathrm{SiQ}^{\mathrm{n}}(\mathrm{mAl})$ units occurring in these structures due to the incorporation of $\mathrm{MgO}$. Besides, it is

345 noted that this $\mathrm{Si}-\mathrm{O}$ stretching band shifted progressively towards greater wavenumber from

$346950 \mathrm{~cm}^{-1}$ for GFM0N5 samples to $980 \mathrm{~cm}^{-1}$ and $985 \mathrm{~cm}^{-1}$ for GFM5N5 and GFM10N5,

347 respectively. These values shift to higher wavenumber could be due to the decreasing of $\mathrm{Al}$

348 substitution in silicate network [53,54] which may be caused by the reaction of $\mathrm{MgO}$ and $\mathrm{Al}-$

$349 \mathrm{O}$ to form $\mathrm{Ht}$.

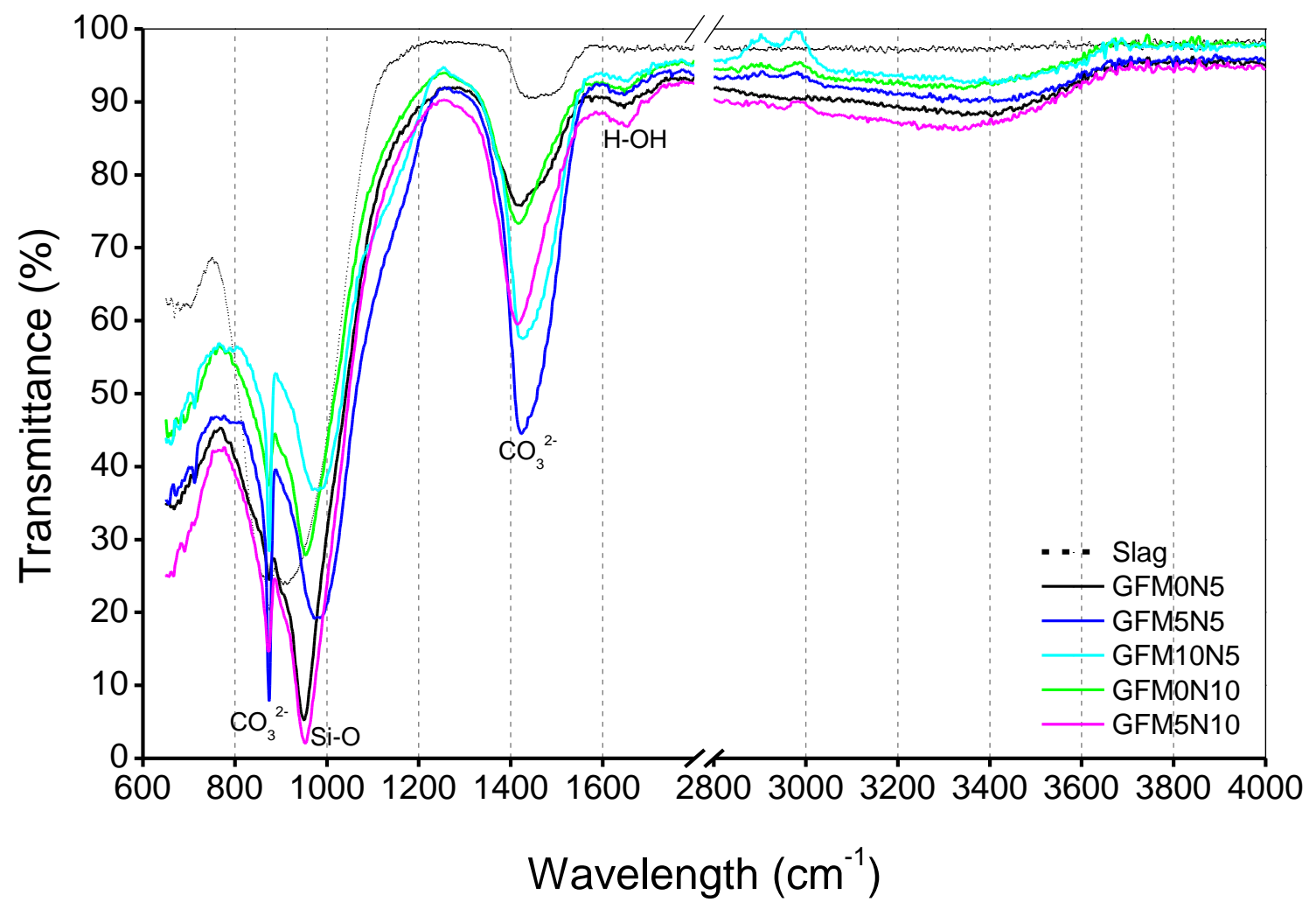

Figure 5. FTIR spectra of selective mixes 28 days 
353 in the bands have been observed with the curing age. However, there was a slight shift of the 354 band at $950 \mathrm{~cm}^{-1}$ at 3 days to a higher wavenumber of $975 \mathrm{~cm}^{-1}$ at 28 days and 180 days 355 indicating more cross-linked and highly siliceous gels due to the reaction of fly ash

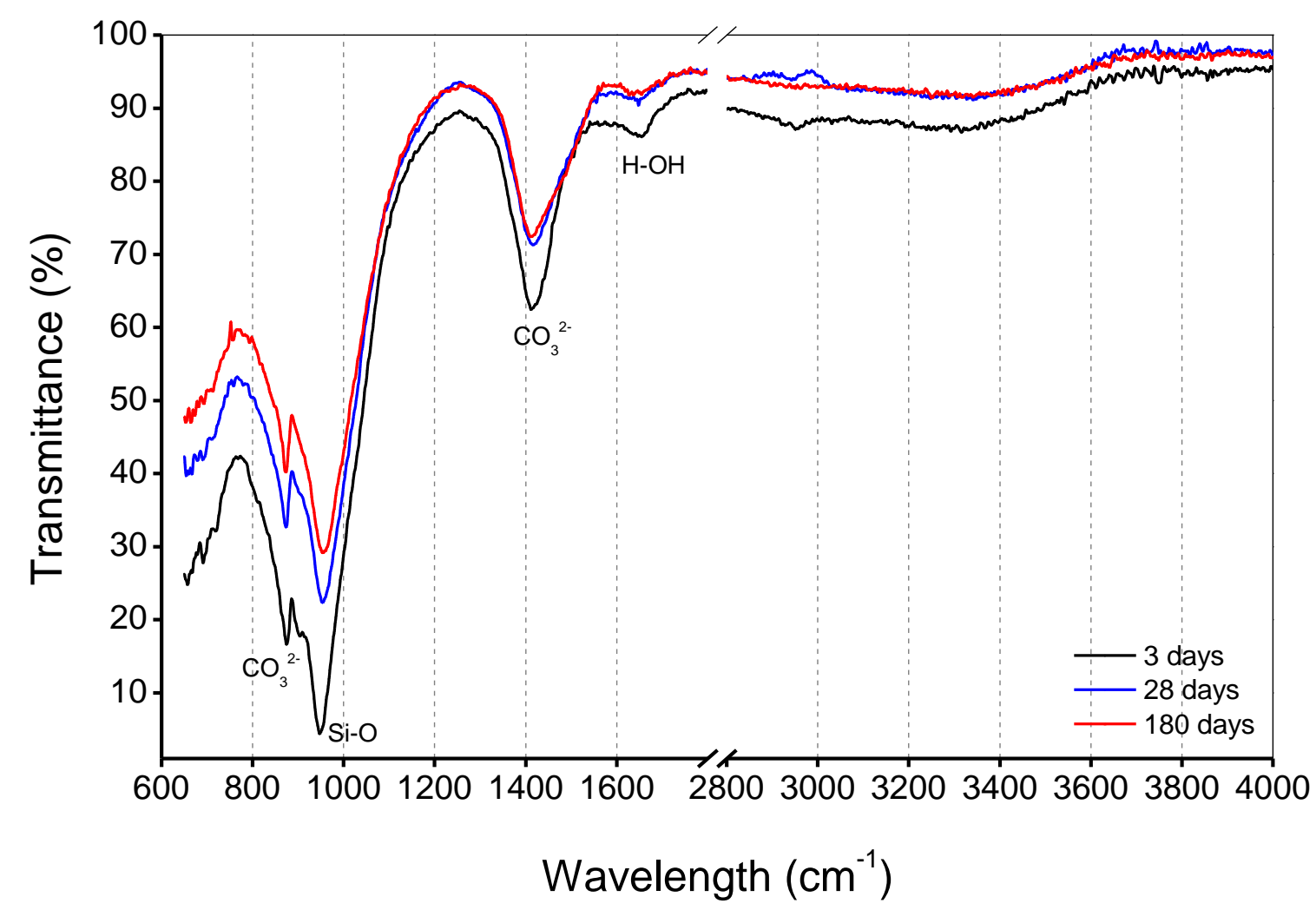

Figure 5. FTIR spectra of the GFM0N10 blend at different ages

\subsection{Microstructural Analysis}

The microstructures of the mixes were quite similar. The micrograph of blends without $\mathrm{Na}_{2} \mathrm{CO}_{3}$ (Fig.7a) shows a loose network and many unhydrated slag grains, which explains the low strength of such blends. Mixes containing both $\mathrm{MgO}$ and $\mathrm{Na}_{2} \mathrm{CO}_{3}$ had a denser microstructure as shown in Fig.7b-d. Some unreacted fly ash particles were shown in the matrixes. 


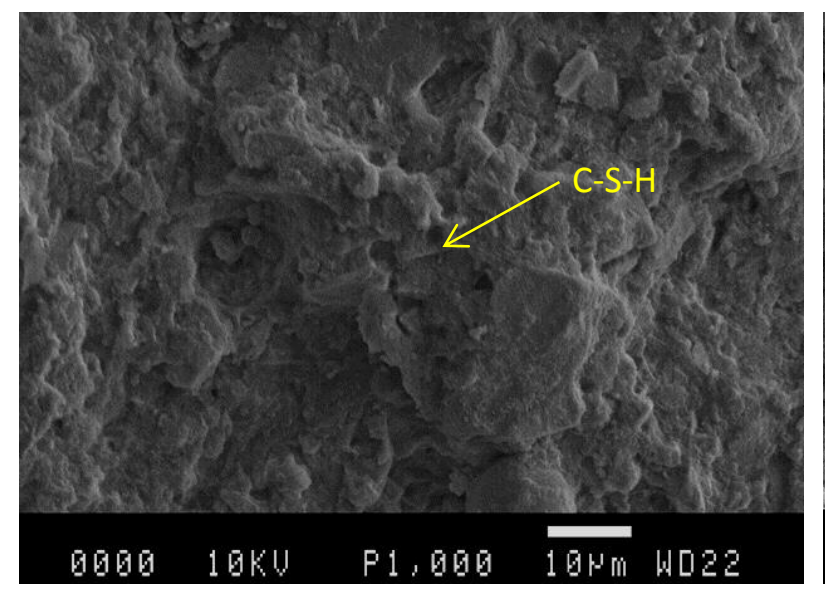

(a)

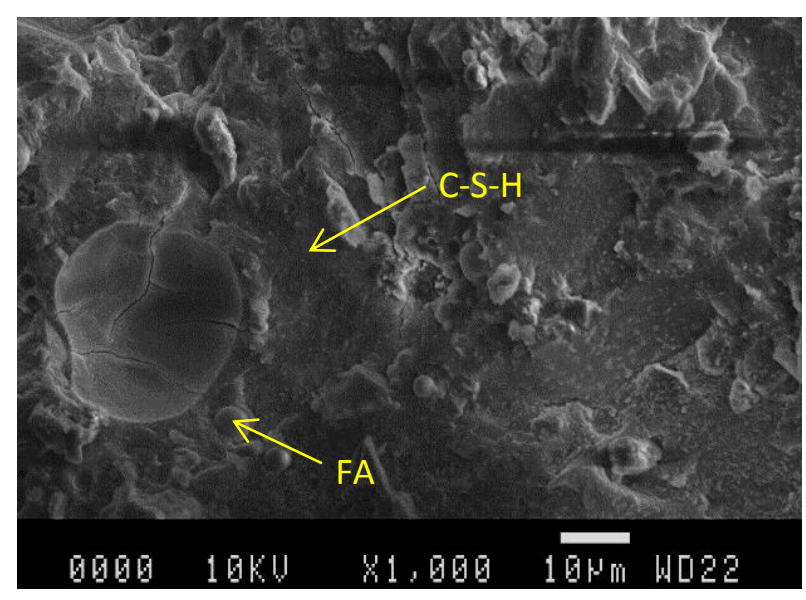

(c)

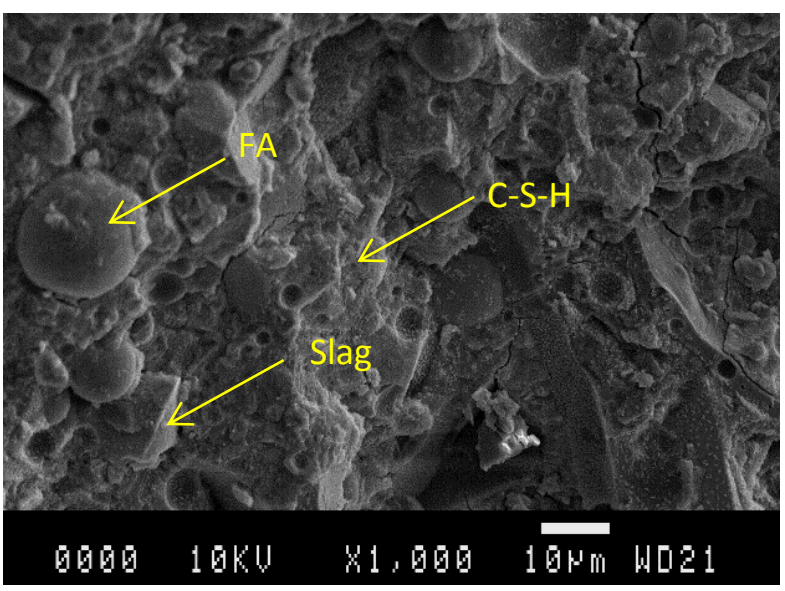

(b)

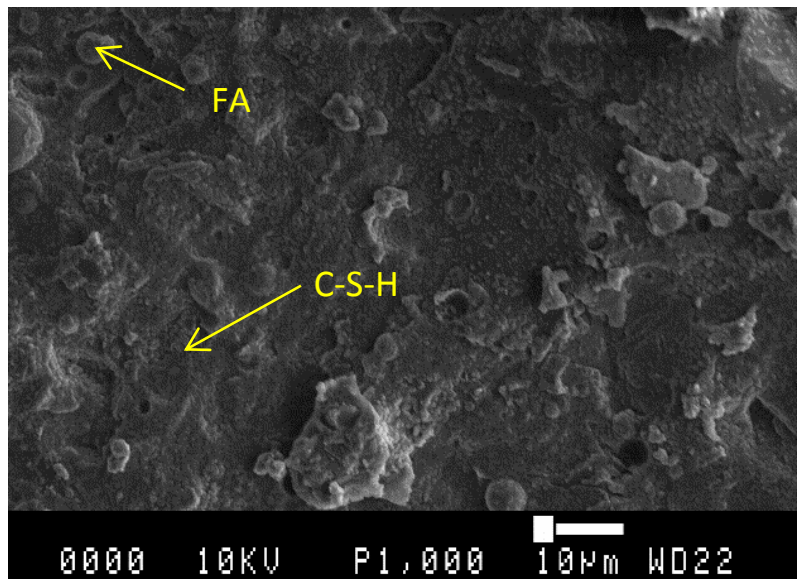

(d)
362

Figure 6. Scanning electron micrographs of the AAFS mixes at 28 days (a) GFM10N0; (b) GFM0N5;

(c) GFM5N5; (d) GFM10N10

In all blends, $\mathrm{C}-\mathrm{S}-\mathrm{H}$ gel is the main feature of the microstructure with some fly ash remaining unreacted. That unreacted particles were easily found suggests that fly ash is not, at least at early ages, interacting with the cementing phase on a chemical level which is not unusual even in AAF (geopolymer) mixtures [10-12]. Regarding the C-S-H gel, it may belong to a low-crystalline calcium silicate hydrate rich in $\mathrm{Al}$, which includes $\mathrm{Na}$ into its structure [12]. 
To determine the elemental composition of the hydration products, EDX were performed on at least 20 points selected on the gels and some of the slag grains in some samples cured for 28 days at a magnification of 2500 on a backscattered mode. Fig. 8a shows that the Al/Si ratio is very high for either a pure chain-structured $\mathrm{C}-\mathrm{A}-\mathrm{S}-\mathrm{H}$ phase $(\mathrm{Al} / \mathrm{Si}<0.2[55])$ or considerable degree of crosslinking [56] so it corresponds to the presence of additional Al-rich products intermixed with Al-substituted C-S-H gel [19]. The good correlation of $\mathrm{Mg} / \mathrm{Si}$ with $\mathrm{Al} / \mathrm{Si}$ indicates the presence of hydrotalcite-like phases (Fig. 8-b), while the presence of a positive $\mathrm{X}$-axis intercept reveals the level of incorporation of $\mathrm{Al}$ in the $\mathrm{C}-\mathrm{S}-\mathrm{H}$ (Table 4). The addition of $\mathrm{MgO}$ slightly changed the gel composition where higher $\mathrm{Ca} / \mathrm{Si}, \mathrm{Al} / \mathrm{Si}$ and $\mathrm{Mg} / \mathrm{Si}$ ratios were detected. From this observation, it may be deducted that the additional alkalis and $\mathrm{MgO}$ lead to immediate increased $\mathrm{pH}$ and therefore increased the dissolution rates of the $\mathrm{Ca}, \mathrm{Si}, \mathrm{Al}$ ions into the solution [57]. The Al-substitution decreased with the increase of $\mathrm{MgO}$ content due to the increased $\mathrm{Al}$ content in hydrotalcite-like phase which was also observed by [29]. The range of $\mathrm{Na} / \mathrm{Si}$ in the investigated samples was from 0.18 to 0.7 as shown in Fig. $8 \mathrm{c}$. The role of $\mathrm{Na}$ in the structure of the reaction products is to balance the negative framework charge induced by the incorporation of $\mathrm{Al}[12,58]$.

According to the EDX analysis, chemical composition of the gel could indicate the formation of hybrid C-(N)-A-S-H gel or the coexistence of N-A-S-H and C-A-S-H intermixed with hydrotalcite gel and M-S-H gel [29,59].

Table 4. Calculated parameters from EDS results at 28 days

\begin{tabular}{ccccccc}
\hline Sample & $\mathrm{Ca} / \mathrm{Si}$ & $\mathrm{Al} / \mathrm{Si}$ & $\mathrm{Mg} / \mathrm{Si}$ & $\mathrm{Na} / \mathrm{Si}$ & $\begin{array}{c}\mathrm{Mg} / \mathrm{Al} \text { (calculated } \\
\text { from Fig. 8b) }\end{array}$ & $\mathrm{Al}$ substitution \\
\hline Slag & 1.19 & 0.40 & 0.36 & 0.09 & 0.7 & - \\
\hline GFM0N10 & 0.83 & 0.43 & 0.30 & 0.53 & 1.94 & 0.28 \\
\hline GFM5N10 & 1.17 & 0.48 & 0.45 & 0.41 & 1.63 & 0.19 \\
\hline
\end{tabular}




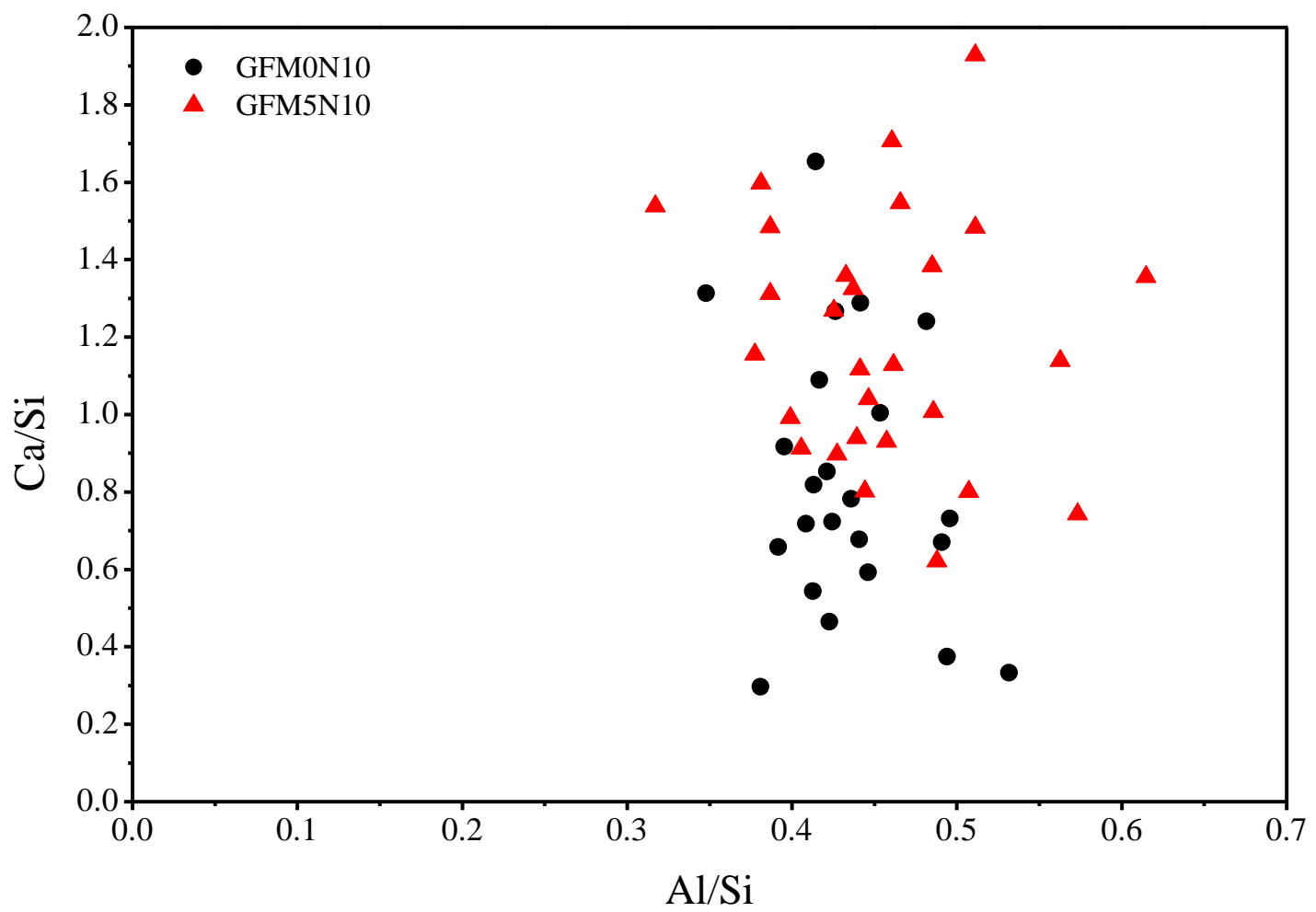

(a)

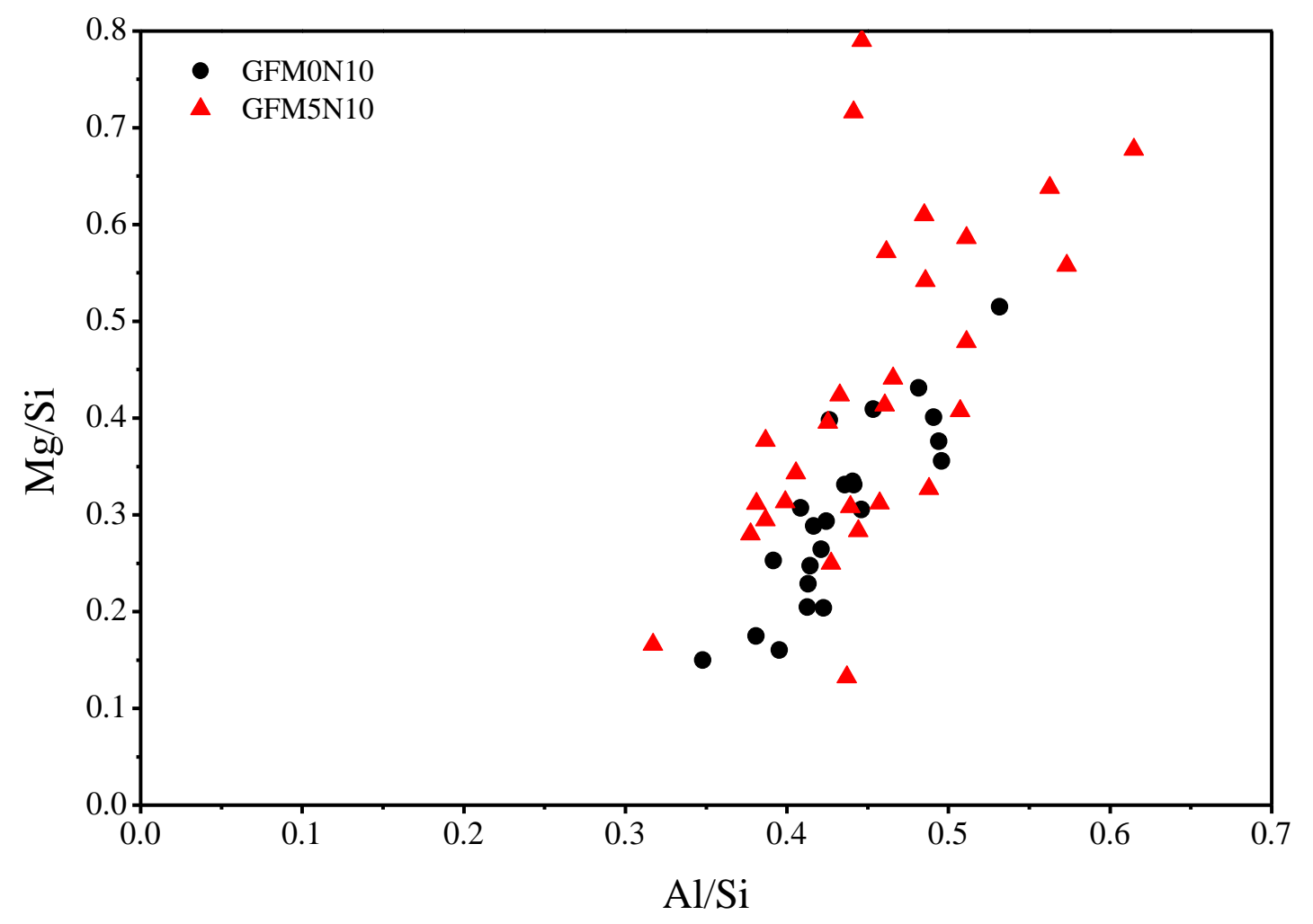

(b) 


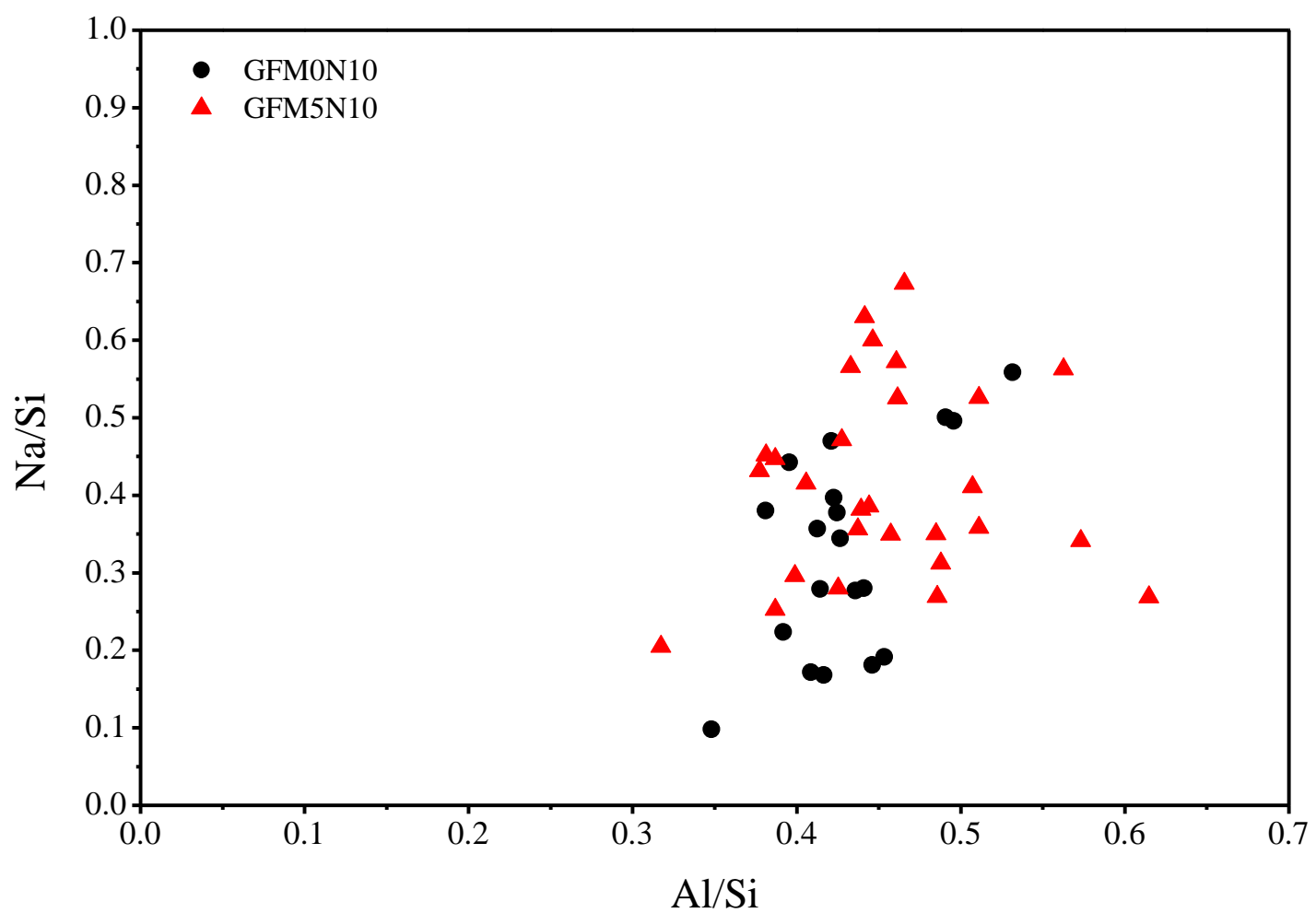

(c)

Figure 7. Atomic ratios for $10 \% \mathrm{Na}_{2} \mathrm{CO}_{3}$ activated mixes with 0 and $5 \% \mathrm{MgO}(\mathrm{A}) \mathrm{Ca} / \mathrm{Si}$ vs $\mathrm{Al} / \mathrm{Si}$, (B) $\mathrm{Mg} / \mathrm{Si}$ vs $\mathrm{Al} / \mathrm{Si}$, and (C) $\mathrm{Al} / \mathrm{Si}$ vs $\mathrm{Na} / \mathrm{Si}$.

\section{Conclusion}

The strength of the AAFS mixes highly depends on the activator dosage and it was clear that increasing the $\mathrm{Na}_{2} \mathrm{CO}_{3}$ dosage increased the strength at all ages. The highest strength obtained was attributed to the paste mix consisting of slag:fly ash in 3:1 ratio and with $10 \%$ of both $\mathrm{Na}_{2} \mathrm{CO}_{3}$ and $\mathrm{MgO}$, which reached $\sim 80 \mathrm{MPa}$ at 90 days. It was found that incorporating $\mathrm{MgO}$ to the blends had a notable influence on the reaction rate, and the microstructure of the mixes and slight influence on the strength. These effects could be beneficial in accelerating the setting time of these blends and the reduction of the shrinkage as will be reported in future studies. The main hydration product was $\mathrm{C}-(\mathrm{N})-\mathrm{A}-\mathrm{S}-\mathrm{H}$ gel as the binding phase in these mixes. Furthermore, other hydration products such as hydrotalcite-like phases, calcite, and gaylussite were formed. 


\section{Acknowledgements}

402

403

404

405

406

407

408

409

410

411

412

413

414

415

416

417

418

419

420

421

422

423

424

425

426

427

428

429

430

431

The financial support of the PhD scholarship for the first author from the Yousef Jameel Foundation and Cambridge Overseas Trust are gratefully acknowledged.

\section{References}

[1] U.S. Geological Survey, Mineral Commodity Summaries: Cement, 2013.

[2] M. Schneider, M. Romer, M. Tschudin, H. Bolio, Sustainable Cement ProductionPresent and Future, Cem. Concr. Res. 41 (2011) 642-650.

[3] D. Higgins, L. Sear, D. King, B. Price, R. Barnes, C. Clear, Cementitious Materials: The Effect of GGBS, Fly Ash, Silica Fume and Limestone Fines on the Properties of Concrete, Surrey, 2011.

[4] B. Suhendro, Toward Green Concrete for Better Sustainable Environment, Procedia Eng. 95 (2014) 305-320.

[5] M. Liska, A. Al-Tabbaa, Ultra-Green Construction: Reactive Magnesia Masonry Products, Proc. ICE - Waste Resour. Manag. 162 (2009) 185-196.

[6] F. Pacheco-Torgal, J. Castro-Gomes, S. Jalali, Alkali-Activated Binders: A Review. Part 2. About Materials and Binders Manufacture, Constr. Build. Mater. 22 (2008) 1315-1322.

[7] F. Pacheco-Torgal, J. Castro-Gomes, S. Jalali, Alkali-Activated Binders: A Review Part 1. Historical Background, Terminology, Reaction Mechanisms and Hydration Products, Constr. Build. Mater. 22 (2008) 1305-1314.

[8] A.M. Rashad, A Comprehensive Overview about the Influence of Different Admixtures and Additives on the Properties of Alkali-Activated Fly Ash, Mater. Des. 53 (2014) 1005-1025.

[9] A.A. Adam, Strength and Durability Properties of Alkali Activated Slag and Fly AshBased Geopolymer Concrete, PhD thesis, RMIT University, 2009.

[10] J.I. Escalante García, K. Campos-Venegas, A. Gorokhovsky, A. Fernández, Cementitious Composites of Pulverised Fuel Ash and Blast Furnace Slag Activated by Sodium Silicate: Effect of Na2O Concentration and Modulus, Adv. Appl. Ceram. 105 (2006) 201-208.

[11] F. Puertas, A. Fernandez-Jimenez, Mineralogical and Microstructural Characterisation of Alkali-Activated Fly Ash/slag Pastes, Cem. Concr. Compos. 25 (2003) 287-292. 
[12] F. Puertas, S. Martinez-Ramirez, T. Vazquez, S. Alonso, Alkali-Activated Fly Ash /Slag Cement Strength Behaviour and Hydration Products, Cem. Concr. Res. 30 (2000) $1625-1632$.

[13] M. Chi, R. Huang, Binding Mechanism and Properties of Alkali-Activated Fly Ash/Slag Mortars, Constr. Build. Mater. 40 (2013) 291-298.

[14] J.S.J. Deventer, J.L. Provis, P. Duxson, D.G. Brice, Chemical Research and Climate Change as Drivers in the Commercial Adoption of Alkali Activated Materials, Waste and Biomass Valorization. 1 (2010) 145-155.

[15] H. Xu, J.L. Provis, J.S.J. Van Deventer, P. V Krivenko, Characterization of Aged Slag Concretes, ACI Mater. J. 102 (2008) 131-139.

[16] S. Wang, K.L. Scrivener, P.L. Pratt, Factors Affecting the Strength of Alkali-Activated Slag, Cem. Concr. Res. 24 (1994) 1033-1043.

[17] A. Fernández-Jiménez, Alkali-Activated Slag Mortars Mechanical Strength Behaviour, Cem. Concr. Res. 29 (1999) 1313-1321.

[18] Y. Li, Y. Sun, Preliminary Study on Combined-Alkali-slag Paste Materials, Cem. Concr. Res. 30 (2000) 963-966.

[19] S. Bernal, J.L. Provis, R.J. Myers, R. San Nicolas, J.S.J. van Deventer, Role of Carbonates in the Chemical Evolution of Sodium Carbonate-Activated Slag Binders, Mater. Struct. (2014) 1-13.

[20] M.A. Shand, The Chemistry and Technology of Magnesia, JOHN WILEY \& SONS, 2006.

[21] Z. Lou, Q. Ye, H. Chen, Y. Wang, J. Shen, Hydration of MgO in Clinker and Its Expansion Property, J. Chin. Ceram. Soc. 26 (1998) 430-436.

[22] X. Li, Mechanical Properties and Durability Performance of Reactive Magnesia Cement Concrete, PhD thesis, University of Cambridge, 2012.

[23] Y. Yi, M. Liska, A. Al-Tabbaa, Properties and Microstructure of GGBS-magnesia Pastes, Adv. Cem. Res. 26 (2014) 114-122.

[24] F. Jin, K. Gu, A. Abdollahzadeh, A. Al-Tabbaa, Effects of Different Reactive MgOs on the Hydration of MgO-Activated GGBS Paste, J. Mater. Civ. Eng. (2013) 1-9.

[25] F. Jin, A. Al-Tabbaa, Characterisation of Different Commercial Reactive Magnesia, Adv. Cem. Res. 26 (2014) 101-113.

[26] M. Ben Haha, B. Lothenbach, G. Le Saout, F. Winnefeld, Influence of Slag Chemistry on the Hydration of Alkali-Activated Blast-Furnace Slag — Part I: Effect of MgO, Cem. Concr. Res. 41 (2011) 955-963. 
[27] W. Shen, Y. Wang, T. Zhang, M. Zhou, J. Li, X. Cui, Magnesia Modification of Alkali-Activated Slag Fly Ash Cement, J. Wuhan Univ. Technol. Sci. Ed. 26 (2011) $121-125$.

[28] T. Kwok, Sustainable Concrete Using Slag and Limestone, Fourth year project report,Cambridge University Engineering Department, 2013.

[29] F. Jin, K. Gu, A. Al-Tabbaa, Strength and Drying Shrinkage of Reactive $\mathrm{MgO}$ Modified Alkali-Activated Slag Paste, Constr. Build. Mater. 51 (2014) 395-404.

[30] F. Jin, A. Al-Tabbaa, Strength and Drying Shrinkage of Reactive MgO and Sodium Carbonate Activated Slag Paste, Constr. Build. Mater. 2015 (accepted Publ. (2015).

[31] A. Abdalqader, A. Al-Tabbaa, Hydration and Mechanical Properties of Reactive Magnesia and Sodium Carbonate-Activated Fly Ash/Slag Paste Blends, in: RILEM PRO092 Proceeding Second Int. Conf. Adv. Chem. Mater. (CAM'2014-China), June 1-3, 2014, Chang. China, RILEM Publications S.A.R.L., Changsha, China, 2014: pp. 269-280.

[32] A.R. Sakulich, E. Anderson, C. Schauer, M.W. Barsoum, Mechanical and Microstructural Characterization of an Alkali-Activated Slag/limestone Fine Aggregate Concrete, Constr. Build. Mater. 23 (2009) 2951-2957.

[33] F. Jin, K. Gu, A. Al-Tabbaa, Strength and Hydration Properties of Reactive MgOActivated Ground Granulated Blastfurnace Slag Paste, Cem. Concr. Compos. 57 (2015) 8-16.

[34] Y. Yi, M. Liska, A. Al-Tabbaa, Initial Investigation into the Use of GGBS-MgO in Soil Stabilisation, in: 4th Int. Conf. Grouting Deep Mix. 2012, American Society of Civil Engineers, Reston, VA, 2012: pp. 444-453.

[35] L.J. Vandeperre, M. Liska, A. Al-Tabbaa, Mixtures of Pulverized Fuel Ash, Portland Cement and Magnesium Oxide: Strength Evolution and Hydration Products, in: Sixth Int. Conf. Sci. Eng. Recycl. Environ. Prot., Belgrade, 2006: pp. 539-550.

[36] L.J. Vandeperre, M. Liska, A. Al-Tabbaa, Hydration and Mechanical Properties of Magnesia, Pulverized Fuel Ash, and Portland Cement Blends, J. Mater. Civ. Eng. 20 (2008) 375-383.

[37] A. Sakulich, Characterization of Environmentally-Friendly Alkali Activated Slag Cements and Ancient Building Materials, $\mathrm{PhD}$ thesis, Drexel University, 2009.

[38] Y. Li, Y. Sun, Preliminary Study on Combined-Alkali-Slag Paste Materials, Cem. Concr. Res. 30 (2000) 963-966.

[39] S. a. Bernal, R. San Nicolas, R.J. Myers, R. Mejía de Gutiérrez, F. Puertas, J.S.J. van Deventer, et al., $\mathrm{MgO}$ Content of Slag Controls Phase Evolution and Structural 
Changes Induced by Accelerated Carbonation in Alkali-Activated Binders, Cem. Concr. Res. 57 (2014) 33-43.

[40] C. Shi, D. Roy, P. Krivenko, Alkali-Activated Cements and Concretes, Taylor \& Francis, Oxon, 2006.

[41] F. Mees, E. Reyes, E. Keppens, Stable Isotope Chemistry of Gaylussite and Nahcolite from the Deposits of the Crater Lake at Malha, Northern Sudan, Chem. Geol. 146 (1998) 87-98.

[42] S. Bernal, J.L. Provis, D.G. Brice, A. Kilcullen, P. Duxson, J.S.J. van Deventer, Accelerated Carbonation Testing of Alkali-Activated Binders Significantly Underestimates Service Life: The Role of Pore Solution Chemistry, Cem. Concr. Res. 42 (2012) 1317-1326.

[43] J.L. Provis, J.S.J. van Deventer, eds., Alkali Activated Materials, Springer Netherlands, Dordrecht, 2014.

[44] Y. Yi, M. Liska, A. Al-Tabbaa, Properties and Microstructure of GGBS-MgO Pastes, Adv. Cem. Res. (2013).

[45] F. Jin, A. Al-Tabbaa, Thermogravimetric Study on the Hydration of Reactive Magnesia and Silica Mixture at Room Temperature, Thermochim. Acta. 566 (2013) 162-168.

[46] P.C. Hewlett, ed., Lea's Chemistry of Cement and Concrete, fourth edi, Elsevier Science \& Technology Books, Oxford, 2004.

[47] I. Ismail, S. a. Bernal, J.L. Provis, S. Hamdan, J.S.J. Deventer, Microstructural Changes in Alkali Activated Fly Ash/slag Geopolymers with Sulfate Exposure, Mater. Struct. 46 (2013) 361-373.

[48] M. Földvári, Handbook of the Thermogravimetric System of Minerals and Its Use in Geological Practice, 213th ed., Geological Institute of Hungary, Budapest, 2011.

[49] I. Ismail, S. Bernal, J. Provis, R. San Nicolas, D.G. Brice, A.R. Kilcullen, et al., Influence of Fly Ash on the Water and Chloride Permeability of Alkali-Activated Slag Mortars and Concretes, Constr. Build. Mater. 48 (2013) 1187-1201.

[50] M. Ben Haha, G. Le Saout, F. Winnefeld, B. Lothenbach, Influence of Activator Type on Hydration Kinetics, Hydrate Assemblage and Microstructural Development of Alkali Activated Blast-Furnace Slags, Cem. Concr. Res. 41 (2011) 301-310.

[51] I. Garcia-Lodeiro, a. Palomo, a. Fernández-Jiménez, D.E. Macphee, Compatibility Studies between N-A-S-H and C-A-S-H Gels. Study in the Ternary Diagram Na2OCaO-Al2O3-SiO2-H2O, Cem. Concr. Res. 41 (2011) 923-931. 
[52] C.A. Rees, J.L. Provis, G.C. Lukey, J.S.J. Van Deventer, Attenuated Total Reflectance Fourier Transform Infrared Analysis of Fly Ash Geopolymer Gel Aging, Langmuir. 23 (2007) 8170-8179.

[53] A. Hajimohammadi, J.L. Provis, J.S.J. Van Deventer, One-Part Geopolymer Mixes from Geothermal Silica and Sodium Aluminate, Ind. Eng. Chem. Res. 47 (2008) 93969405.

[54] W. Mozgawa, J. Deja, Spectroscopic Studies of Alkaline Activated Slag Geopolymers, J. Mol. Struct. 924-926 (2009) 434-441.

[55] W. Hunnicutt, Characterization of Calcium-Silicate-Hydrate and Calcium-AluminoSilicate-Hydrate, Master thesis, University of Illinois at Urbana-Champaign, 2013.

[56] R.J. Myers, S. Bernal, R. San Nicolas, J.L. Provis, Generalized Structural Description of Calcium-Sodium Aluminosilicate Hydrate Gels: The Cross-Linked Substituted Tobermorite Model., Langmuir. 29 (2013) 5294-306.

[57] E. Deir, B.S. Gebregziabiher, S. Peethamparan, Influence of Starting Material on the Early Age Hydration Kinetics, Microstructure and Composition of Binding Gel in Alkali Activated Binder Systems, Cem. Concr. Compos. 48 (2014) 108-117.

[58] P. Duxson, A. Fernández-Jiménez, J.L. Provis, G.C. Lukey, A. Palomo, J.S.J. Deventer, Geopolymer Technology: The Current State of the Art, J. Mater. Sci. 42 (2006) 2917-2933.

[59] N. Marjanović, M. Komljenović, Z. Baščarević, V. Nikolić, R. Petrović, Physicalmechanical and Microstructural Properties of Alkali-Activated Fly Ash-blast Furnace Slag Blends, Ceram. Int. 41 (2015) 1421-1435. 